Florida International University FIU Digital Commons

3-30-2011

\title{
Implicit metaphysis of the Visuddhimagga : assāsa- passāsa as a vital animating force
}

Elena Cecelia Amato

Florida International University

DOI: $10.25148 /$ etd.FI14032304

Follow this and additional works at: https://digitalcommons.fiu.edu/etd

Part of the Religion Commons

\section{Recommended Citation}

Amato, Elena Cecelia, "Implicit metaphysis of the Visuddhimagga : assāsa-passāsa as a vital animating force" (2011). FIU Electronic Theses and Dissertations. 1276.

https://digitalcommons.fiu.edu/etd/1276

This work is brought to you for free and open access by the University Graduate School at FIU Digital Commons. It has been accepted for inclusion in FIU Electronic Theses and Dissertations by an authorized administrator of FIU Digital Commons. For more information, please contact dcc@fiu.edu. 


\section{FLORIDA INTERNATIONAL UNIVERSITY}

Miami, Florida

IMPLICIT METAPHYSICS OF THE VISUDDHIMAGGA:

ASSĀSA-PASSĀSA AS A VITAL ANIMATING FORCE

A thesis submitted in partial fulfillment of the

requirements for the degree of

MASTER OF ARTS

in

RELIGIOUS STUDIES

by

Elena Cecelia Amato

2011 
To: Dean Kenneth Furton

College of Arts and Sciences

This thesis, written by Elena Cecelia Amato, and entitled Implicit Metaphysics of the Visuddhimagga: Assāsa-passāsa as a Vital Animating Force, having been approved in respect to style and intellectual content, is referred to you for judgment.

We have read this thesis and recommend that it be approved.
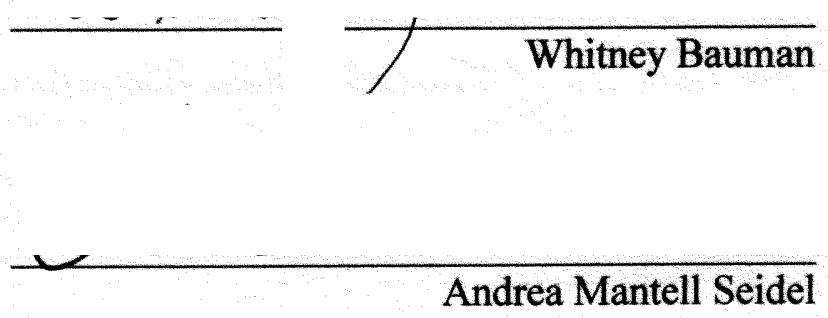

Nathan Katz, Major Professor

Date of Defense: March 30, 2011

The thesis of Elena Cecelia Amato is approved.

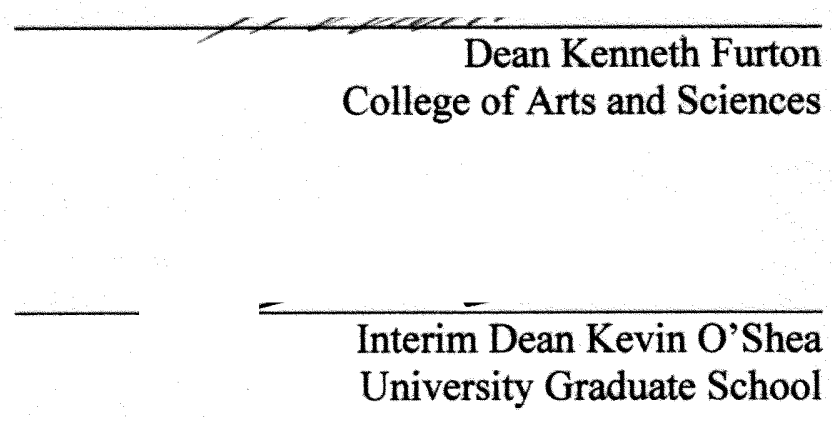

Florida International University, 2011 


\section{ACKNOWLEDGMENTS}

I wish to thank the members of my committee for their flexibility, support, and guidance during the writing of my thesis and for showing me what it means to be a student and teacher of Religious Studies. I especially want to acknowledge and thank my major professor, Dr. Nathan Katz, for taking this project on amidst uncertain beginnings, for giving me direction when I most needed it, and for opening doors. For his attention to detail, inexhaustible knowledge of Buddhism, and all the lessons learned through each, I have much gratitude. I am also thankful for Dr. Andrea Mantell Seidel's unflagging encouragement, support, and balancing lessons, with which I have learned to ground and pace myself. And for Dr. Bauman's cheerful willingness to contribute time and wisdom to this project, my sincerest thanks. 


\section{ABSTRACT OF THE THESIS \\ IMPLICIT METAPHYSICS OF THE VISUDDHIMAGGA: \\ ASSĀSA-PASSĀSA AS A VITAL ANIMATING FORCE \\ by}

Elena Cecelia Amato

Florida International University, 2011

Miami, Florida

Professor Nathan Katz, Major Professor

This research examines how assāsa-passāsa and its surrounding concepts are discussed in Buddhaghossa's $5^{\text {th }}$ century Theravada work, the Visuddhimagga (The Path of Purification) to determine if there is metaphysical use of the term in the text and to determine if the concept of assāsa-passāsa is similar to the better-known Indian concept of prāna (metaphysical vital animating force), indicating whether Theravada Buddhism more closely resembles other Indian religions in terms of metaphysical content. Text analysis reveals how assāsa-passāsa is described in the Visuddhimagga as an animating vital force, suggesting that Theravada Buddhism has an implicit ontology similar to other Indian schools of philosophy. Secondarily, this paper argues that because assāsa-passāsa plays a similar role to prāna in the Visuddhimagga, it is also operationally similar and could be functioning as the implicit intermediary between links in the chain of dependent co-arising - as the vehicle of paticcasamuppāda. 


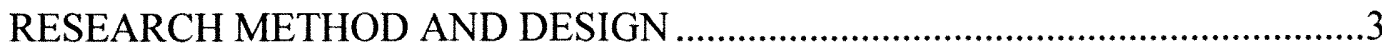

HISTORICAL BACKGROUND ….......................................................................

Gautama Buddha to the Writing of the Pali Canon: Theravada's Emigration from

India to Sri Lanka

The Writing and Contents of the Pali Canon ........................................................11

The First Literary Period to Extinction of the Lambhaka Dynasty..........................14

Bhadantacariya Buddhaghosa and the Visuddhimagga ..........................................15

A Note on the English Translator, Bhikkhu Nanamoli ............................................19

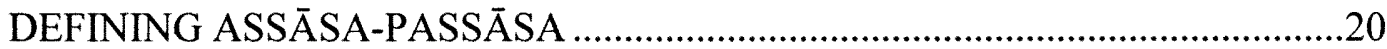

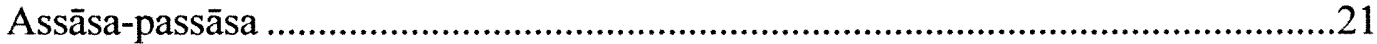

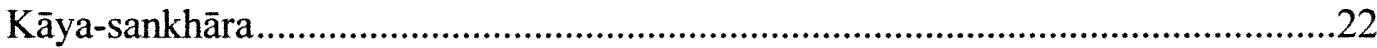

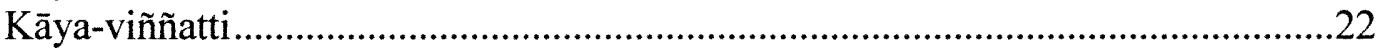

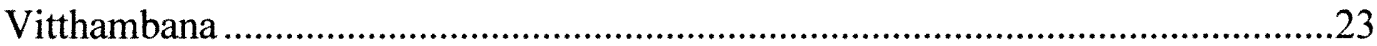

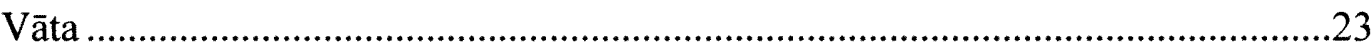

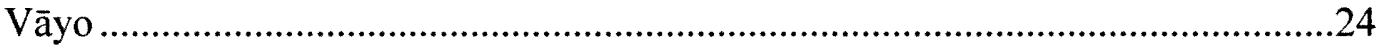

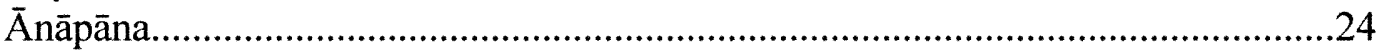

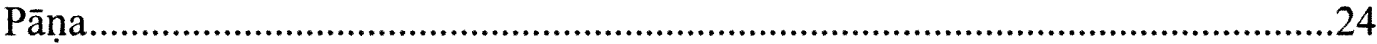

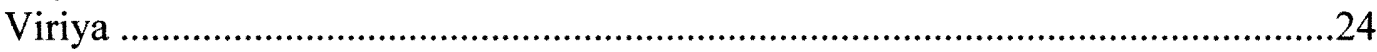

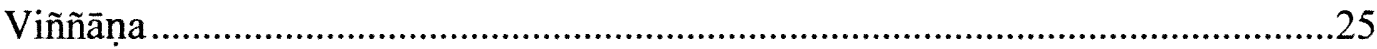

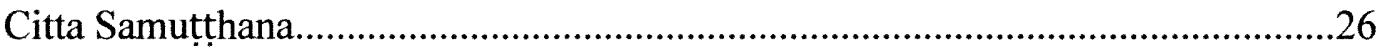

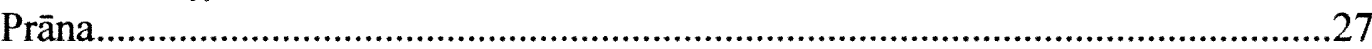

ASSĀSA-PASSĀSA IN THE VISUDDHIMAGGA: THE SEARCH FOR A

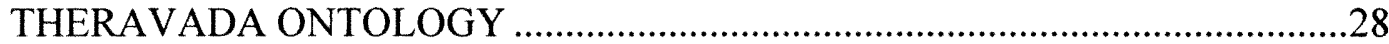

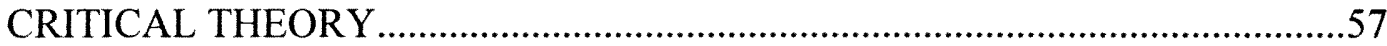

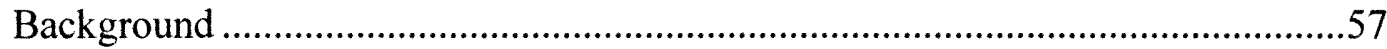

Scholars on Theravada Cosmology, Metaphysics and Breath ...............................59

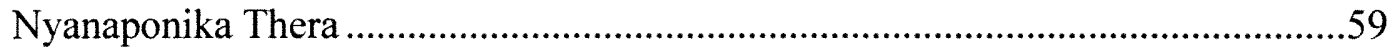

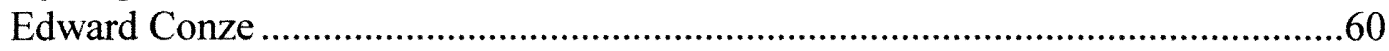

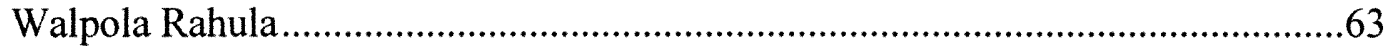

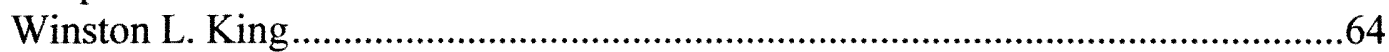

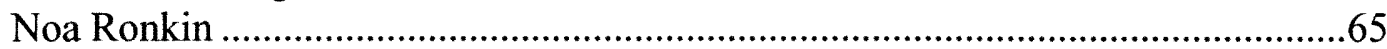

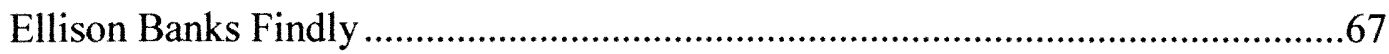

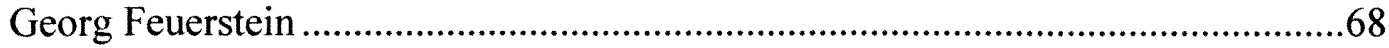

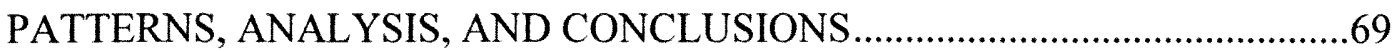




\section{Introduction}

The Pali term assāsa-passāsa, meaning 'breathing out and in,' 'sign of life,' 'process of breathing,' and 'breath' is an obscure and often overlooked concept in scholarship on Theravada Buddhism. The gap in knowledge exists because questions of metaphysics, abstruse philosophies of existence, causation and reality, have historically been deemed unimportant and therefore ignored in scholarship on the Theravada school. Though recent scholars have begun to discuss Theravada metaphysics, their work falls entirely within the "process philosophy" perspective, a paradigm which mirrors the doctrinal logos of paticcasamuppāda (dependent co-arising) and which proclaims that all that exists is interdependent and without substance. A purposeful omission that process philosophy and paticcasamuppāda make is declaration of the medium through which causative processes operate and interrelate. It is in the wake of this omission and the limitations of process philosophy that the concept of assāsa-passāsa opens discourse for a new paradigm in Theravada metaphysics.

Assāsa-passāsa, distinct from its thoroughly analyzed semantic relative, ānāpāna-sati (mindfulness of breathing), is not a central tenet in Theravada Buddhism; instead, assāsapassāsa illuminates human life-force, animation, and bodily-formation within a cosmology of paticcasamuppäda (dependent co-arising). The essential supporting terms to this understanding of assāsa-passāsa are: kāya-sankhāra (bodily formation or 'inbreath and out-breath'), kāya-viññatti (bodily intimation), vitthambhana (distension), vāta (air, wind), vāyo (air, wind), ānāpāna (breathing), pāṇa (breathing thing, living thing), viriya (energy, vigor), viññāna (consciousness), and citta samutțhana 
(consciousness-originated [matter]). By studying the application of these words in Theravada texts, a conceptual image of breath emerges.

The ensuing pages examine the way assāsa-passāsa and its surrounding concepts are discussed in the foremost Theravada commentarial text, Bhadanticariya Buddhaghossa's $5^{\text {th }}$ century work, the Visuddhimagga (The Path of Purification), to determine whether an underlying ontology, that is, a theoretical and existential account of the systemic entities of 'breath' is present therein. Specifically, this research has defined, explored, and analyzed the concept of assāsa-passāsa in the Visuddhimagga with two purposes: (1) to determine if there is metaphysical use of the term in the text, and (2) to determine if the concept of assäsa-passäsa is similar to or distinct from the better-known Indian concept of prāna (metaphysical life-giving breath/air/energy) and therefore whether Theravada Buddhism might more closely resemble other Indian religions in terms of metaphysical content.

Though änāpāna-sati (mindfulness of breathing) is a thoroughly discussed concept in primary texts and commentarial Theravada discourse, the term assāsa-passāsa has never, within this school of Buddhism, received the same attention. This research asks, for the first time in Western literature, if assāsa-passāsa, concurrent with its centrality as a meditative tool, is portrayed in one of the earliest and most authoritative Theravada texts as a metaphysical force of animation, and if so, how that force is described. This question is of great import because it demands one of two conclusions: (1) should metaphysical discourse of breath be found, the claim that Theravada Buddhism is free of such ontological discussions is disproven; (2) should no metaphysical discourse of breath be found, this would suggest that Theravada Buddhism is radically unique from all other 
Indian religions because it does not possess a metaphysical conception of 'life-force' or prāṇa.

What the findings of this study reveal is that assāsa-passāsa is, in fact, described in the Visuddhimagga as an animating vital force, similar in nature to prāṇa, proving that Theravada Buddhism is neither unique among Indian religions for its lack of this concept nor for being an 'a-metaphysical' school, showing conclusively that a Theravada ontology exists. Secondarily, this paper argues that because assāsa-passāsa assumes the role of prāna in the Visuddhimagga, it is also operationally similar to prāna and could be functioning as the implicit intermediary between links in the chain of dependent coarising, giving way to the 'how' of paticcasamuppāda.

\section{Research Method and Design}

This research follows an expository-analytical model. First to be presented is an overview of the origins of Buddhism in $6^{\text {th }}$ century B.C.E. India and the socio-political currents of Sri Lanka up to the $5^{\text {th }}$ century C.E. This history is followed by an introduction to Bhadantacariya Buddhaghosa, the Visuddhimagga, Bhikkhu Nanamoli (the Pali-English text translator) and a chapter outlining the terms central to this research. Secondly, but primarily, is the intention to explore assäsa-passāsa, to explore the terms closely related to breath, energy, and air in the Visuddhimagga, and to examine their representation, roles, or relationship to the idea of an animating vital force or prāna. The primary terms of inquiry are: kāya-sankhāra, kāya-viññatti, vitthambhana, vāta, vāyo, ānāpāna, pāna, viriya, viññāna, and citta samutțhana. Together they are represented in 95 passages and notes in Bikkhu Ñanamoli's English translation of the text. 
This study uses Bikkhu Nanamoli's translation because it is the more recent of the two full existing translations and widely respected as the most rigorously accurate. Although this English translation is of high integrity, it will, of course, suffer the minor shifts in message and understanding that are the unavoidable byproducts of any translation effort. Understandably then, it would be most beneficial for a project in the future to perform a mirror investigation into Buddhaghosa's Visuddhimagga in its original Pali to test out the findings of this study.

After presenting these terms as they appear in the Visuddhimagga, the paper will also consider the notes made on the subject of cosmology and ontology in Theravada Buddhism by modern scholars. The term 'cosmology' is used here to discuss and indicate the Theravadin "stories", implicit and explicit in the texts, that give explanation to the origin, evolution, and structure of the universe while 'ontology' will always reference the operational systems and respective entities of said universe - the mechanics. The word 'metaphysical' is also used frequently, acting as an umbrella term over the fields of cosmology and ontology so that comprehensive discussions of "that which is unseen" and "the nature of reality" may be held. Finally the study will discuss and analyze the major patterns that arise from the collection of passages carrying the term and related concepts of assāsa-passāsa in the Visuddhimagga and discuss the significance of this paper's findings. 


\section{Historical Background}

\section{Gautama Buddha to the Writing of the Pali Canon: Theravada's Emigration from India to Sri Lanka}

Some 500 years before Christ, the presumed historical person Siddhartha Gautama was born into an era of philosophical and spiritual renaissance and would, at a young age, go on to discover and then profess a revolutionary spiritual path of his own. The former prince called his realization Dhamma-Vinaya (Doctrine and Discipline) and his message reached people from every corner of India. Though the Buddha taught the Way with crystalline clarity, once he passed from this world, those pursuing the path could no longer receive direct guidance. They would have to rely on the memories of his disciples for the steps of the Path.

There are necessary ineptitudes of personal and collective memory, even when those memories as said to have belonged to enlightened beings like the arahants, and it is for this reason that an attentive eye must be applied to how, where, and why Theravada doctrine developed. For our purposes especially, a survey of the political, environmental, religious, doctrinal, and social movements from early Buddhism to the crystallization of

Sri Lanka's high Theravada culture of the $5^{\text {th }}$ century C.E., the time of Buddhaghosa, is necessary for us to expose and understand the content and influences of the

\section{Visuddhimagga.}

Following the Buddha's parinibbana, a First Council of 500 arahants was gathered by Mahakasyapa to determine the official doctrine and discipline of the Enlightened One. The Buddha's attendant, Ananda, recited the Dhamma or "the remembered words of the 
Buddha", and Upali recited the Vinaya or "rules of conduct". Their recitations of the Sutta-Pitaka and Vinaya-Pitaka were accepted by those present, thus shortly after parinibbana, the first two sections of the Pali Buddhist Canon, the Tipitaka, were formed. The third, the Abhidhamma Pitaka, a collection of meditative matrices, polemics, and exegesis, followed sometime later, but in addition to appearing in varying versions, it was not universally accepted by the Sangha. Some among those who accepted it, recognized Ananda as the bearer of the Abhidhamma, but as schisms were occurring within the Sangha, the canonical teachings were no longer universal because the only record keeping was oral. Today "our knowledge of the doctrine taught by the Buddha himself still remains rather vague and conjectural". ${ }^{2}$

The Buddhist doctrinal scholar Barua explains the fissuring of Buddhism into sects and schools as the result of two factors. First, Siddhartha had left behind no single human successor or authoritative institution, and second, the Canon was carried only by memory and oral transference for some five centuries. ${ }^{3}$ These two characteristics of early Buddhism left ample room for struggles of authority, disagreements over theory and practice, and invention, all of which were well underway by 250 B.C.E. and persist to the present day.

The struggle divided the Buddhist sangha early on into what Mahayana polemics call Mahayana and Hinayana, the "Large Vehicle" and "Small Vehicle" respectively. These

\footnotetext{
${ }^{1}$ Lancaster, Lewis R., Encyclopedia of Religion; Buddhist Books and Texts: Canon and Canonization, ed. Lindsay Jones. 2nd ed. Vol. 2. (Detroit: Macmillan Reference USA, 2005), 1252.

${ }^{2}$ Bareau, Andre. Encyclopedia of Religion; Buddhism, Schools of: Early Doctrinal Schools of Buddhism, ed. Lindsay Jones. 2nd ed. Vol. 2. (Detroit: Macmillan Reference USA, 2005), 1192.

${ }^{3}$ Ibid., 1193.
} 
factions were to become diversified into many smaller sects. One of the so called Hinayana sects, the Vibhajyavadins ("those who teach discrimination"), sent missionaries to Sri Lanka during Asoka's reign in the $3^{\text {rd }}$ century B.C.E. and "Adopting Pali as a canonical language and energetically claiming their teaching to be the strict orthodoxy, they took the name Theravadins, a Pali form of the Sanskrit Sthaviravadins." In Sri Lanka, they too underwent schisms, the Abhayagirivasins separating from the Mahaviharans before the 1st century C.E., and the Jetavaniyas again from the Mahaviharans in the $4^{\text {th }}$ century C.E. But it is the founding Sri Lankan Mahavihara Theravadins and their persistent tradition whose written works, specifically the paragon $5^{\text {th }}$ century C.E. Tipitaka commentary, The Path of Purification, which is the subject of this paper.

Again, to understand the Pali Canon and The Path of Purification, the history and culture of Sri Lanka must be explored to properly analyze the works produced there. Well before Buddhists arrived on the island, Sri Lanka was inhabited by a number of other peoples. Buddhist scholar and philosopher E.W. Adikaram names the Yakkha and the Naga as the indigenous tribes of ancient Sri Lanka ${ }^{5}$ while historian K.M. DeSilva names the Balangoda as the people who had inhabited the island for many millennia before the Sinhalese hero Vijaya arrived from the Gangetic Plain with his language, culture, and religion in the $5^{\text {th }}$ century B.C.E. ${ }^{6}$ In addition to whatever indigenous

\footnotetext{
${ }^{4}$ Ibid., 1194.

${ }^{5}$ Adikaram, E. W., Early History of Buddhism in Ceylon : Or, State of Buddhism in Ceylon as Revealed by the Päli Commentaries of the 5th Century A.D. (Migoda, S. Puswella. 1946), 43.

${ }^{6}$ De Silva, K. M., A History of Sri Lanka (Berkeley: University of California Press, 1981), 7.
} 
populations occupied the island, Vijaya's people were also preceded by populations of Tamil Indians in the south and Sanskrit-Pakrit speakers in the north. By c.a. 400 B.C.E., Sri Lanka was already host to a pastiche of ancient folk and Indian traditions.

DeSilva argues that Dravidians from the Nubian region [sic] of South India began to arrive in Sri Lanka approximately 20 years before the legendary arrival of Vijaya and his clan and even calls Vijaya a mythological figure. He goes on to point out that no strong division existed between the Sihalese and Dravidians living on the island in the preBuddhist age - that is, the two often intermixed and interbred - and his second assertion is that Buddhism in Sri Lanka predated Mahinda's $1^{\text {st }}$ century B.C.E. arrival. ${ }^{7}$ As for the latter assertion, Adikaram concurs. ${ }^{8}$ Whether there is truth in this theory is highly debated, and there has yet been no way to solidify if and of what kind pre-Mahinda Sri Lankan Buddhism was or how much influence it held.

But it is evident that the cultural milieu into which the stronghold of Theravada Buddhism was to be inserted contained strong Brahmanic and Vedic influence brought by the Sinhalese and other Indo-Aryan clansmen. Other influences included Yaksa and tree deity worship, animism, Jainism, Ajivikism (stoicism), Paribbajakism (spiritual 'wandering'), sophism, asceticism, and feasibly versions of Buddhism as well. The sources ranged from the earliest of native folk traditions to the influx of (especially North

\footnotetext{
${ }^{7}$ Ibid., 9-13.

${ }^{8}$ Adikaram, Early History of Buddhism in Ceylon, 46.
} 
Indian) immigrants and visitors who began pouring into the island around the time of the alleged Vijaya. ${ }^{9}$

The centuries preceding Buddhism's dominance in Sri Lanka were relatively peaceful even while dominated by change and movement. During the reign of King Devanampiya Tissa, who according to DeSilva tried in vain to assume rulership of the entire island, the government was already looking to establish religious and political ties with the vast and powerful Mauryan Empire of India. ${ }^{10}$ Therefore, when Thera Moggaliputta (head of the Buddhist church [sic]) dispatched Ashoka's close relative and devout monk Mahinda as a Buddhist missionary to Sri Lanka at the Emperor's bequest, Devanampiya Tissa was more than willing to convert personally and to facilitate the conversion of his kingdom. ${ }^{11}$ The Mahavamsa tells the story a little differently, ignoring the political impetus and instead glorifying Mahinda's miraculous arrival and Devanampiya Tissa's spontaneous and radical conversion. In any case, all sources, including Ashoka's $13^{\text {th }}$ Edict and other archaeological evidence corroborate Mahinda's legendary arrival in Sri Lanka in 247 B.C.E. ${ }^{12}$ As for his version of Buddhism, the Theravada scholar Panabokke writes that Mahinda's Mahavihara establishment can be described as a "Theravada Vinaya School" that emphasized patipatti (practice) over pariyatti (learning). ${ }^{13}$

\footnotetext{
${ }^{9}$ Ibid., 43-45.

${ }^{10}$ DeSilva, A History of Sri Lanka, 14.

${ }^{11}$ Panabokke, Gunaratne B., and University of Kelaniya Postgraduate Institute of Pali \& Buddhist Studies. History of the Buddhist Sangha in India and Sri Lanka. (Colombo: University of Kelaniya, 1993), 71.

${ }^{12}$ Adikaram, Early History of Buddhism in Ceylon, 49.

${ }^{13}$ Panabokke, History of the Buddhist Sangha in India and Sri Lanka, 79.
} 
At Mahinda's behest, Devanampiya Tissa immediately commissioned the Mahavihara monastery to be built in his capital city of Anuradhapura and to procure every necessary comfort and amenity for Mahinda's entourage. The latter's sister, the nun Sanghamitta, is said to have arrived shortly thereafter bearing a shoot from the Bodhi tree and a collarbone relic, and as Mahinda established the Mahavihara monastic community and Devanampiya Tissa enshrined the relic and planted the sapling, Sanghamitta founded the Bhikkhuni Sangha (order of nuns) in the same city. ${ }^{14}$ As if the self-appointed maharaja had not made it clear enough already, he decreed Buddhism the official state religion. Interestingly enough, and perhaps because of the rapid transition period, the court retained an apparently immutable system of Brahmanical ritual and simply syncretized it with elements of Buddhism. The general population was no different. Any given individual might practice a peculiar mélange of Buddhism, animism, and/or Brahmanism. ${ }^{15}$ An example which lends itself well to this practice is the common belief that the Hindu chief of gods, Indra, was instrumental in Mahinda's efforts to convert the island to Buddhism... an oxymoron in orthodox Theravada to say the least. ${ }^{16}$

Anuradhapura would not reign supreme for long, however. Panabokke explains that Tamils from South India invaded the island and assumed power in Anuradhapura only to be usurped half a century later by the Sinhalese. ${ }^{17}$ As would become quotidian for the next thousand years, political instability erupted not long after Anuradhapura was

\footnotetext{
${ }^{14}$ Robinson, Richard H., and Willard L. Johnson. The Buddhist Religion : A Historical Introduction. $2 \mathrm{~d}$ ed. (Encino: Dickenson Pub. Co., 1977), 144.

${ }^{15}$ Ibid., 144.

${ }^{16}$ Adikaram, Early History of Buddhism in Ceylon, 50.

${ }^{17}$ Panabokke, History of the Buddhist Sangha in India and Sri Lanka, 81.
} 
resettled, the Tamils and the Sinhalese wresting power from one another until the turn of the first century. But it was this instability that became an unlikely blessing in disguise for Theravada Buddhists around the world. For when King Vattagamani regained the throne in 31 B.C.E., the Tipitaka was about to be transcribed for the first time. ${ }^{18}$

\section{The Writing and Contents of the Pali Canon}

Around the year 43 B.C.E. when Vattagamani had first ascended to power, almost every force imaginable prevented him from success. Initially, a Brahman from Rohana staged a coup, but even his violent disruption was soon usurped by non-Buddhist invaders (presumably from South India), and a twelve-year long famine followed. ${ }^{19}$ When the dust settled and Vattagamani returned from exile, monks migrated back to Anuradhapura from South India, Sri Lanka's forests and caves, and other safe havens. From there, one version of the story rendered is that a council of the surviving monks, concurring that efforts must be waged to preserve the teachings of the Buddha in their purity, had retreated to a cave $\mathrm{e}^{20}$ that housed a small monastery at Getambé in the Central Province in the year 29 B.C.E. to record the Theravada Canon in the Pali language. ${ }^{21}$ The other version, which Lancaster calls "the traditional view", gives King Vattagamani a more central role in putting the scriptures to paper. He is said to have called the Fourth Council in Anuradhapura, bringing the monk Mahendra forward to recite the three Pitakas in their entirety. Vattagamani then commissioned five hundred scribes and

\footnotetext{
${ }^{18}$ Prebish, Charles S., The A to Z of Buddhism, (Lanham: Scarecrow Press, 2001), 10.

${ }^{19}$ Ibid., 84.

${ }^{20}$ Robinson and Johnson, The Buddhist Religion: A Historical Introduction, 144.

${ }^{21}$ Panabokke, History of the Buddhist Sangha in India and Sri Lanka, 85.
} 
reciters to write the Canon down. Lancaster qualifies the validity of this version of history by noting that the contents of the Theravada Canon were not settled for another 400-500 years. ${ }^{22}$ Legend also has it that the Tipitaka was not only recorded on ola leaves for preservation, but that it was concurrently etched into gold tablets and buried at the Aloka-vihara. ${ }^{23}$

The monks' use of language was a simple choice because Pali was the language of the Canon's oral transmission to and within the island by Mahinda and was believed to be the language spoken by the Buddha. Most contemporary scholars believe that Pali must already have been in use on the island, otherwise the people there would not have been able to understand Mahinda's preaching. If their argument is true, it would indicate that Pali and/or a close relative was spoken by the Sinhalese in Sri Lanka before Buddhism came to be the state religion.

The Pali Canon, unique as each sectarian canon that has ever emerged within Buddhism but more special than all because it is the only full Canon to have survived to modern times, is comprised of the three Pitakas (books or lit. baskets), the Sutta Pitaka (basket of sermons), Vinaya Pitaka (basket of discipline), and the Abhidhamma Pitaka (basket of higher teachings). The Sutta Pitaka

Is composed of five Nikayas or "groupings," bringing together the "long" (digha), "medium" (majjhima), and "grouped" (samyutta) sermons; those arranged according to a number of categories (ariguttara); and, lastly the "minor" (khuddaka) sermons, the longest and most varied section of all. The Khuddaka Nikaya assembles the legends of the former "births" (jataka) of the Buddha,

\footnotetext{
${ }^{22}$ Lancaster, Lewis R., Encyclopedia of Religion; Buddhist Books and Texts: Canon and Canonization, ed. Lindsay Jones. 2nd ed. Vol. 2., (Detroit: Macmillan Reference USA, 2005), 1252.

${ }^{23}$ Adikaram, Early History of Buddhism in Ceylon, 79.
} 
legends recounting the "deeds" (apadana; Skt. avadana) of the great disciples, didactic stanzas (gatha) attributed to them, a famous but anonymous collection of other instructional stanzas called the Dhammapada, and ten or so other equally varied works. $^{24}$

The Sutta Pitaka is the collection that speaks to the broadest Theravada Buddhist community, containing messages for the lay and monastic alike. Conversely, the Vinaya Pitaka is a guidebook for bhikkus (monks) and bhikkunis (nuns). It lists, in exhaustive detail, the rules of monastic life, including disciplinary matters and instructions on managing material objects and participation in the material world. ${ }^{25}$ Lastly, the

\section{Abhidhamma Pitaka}

Consists of seven different works, in which the doctrine set forth in no particular order in the sermons (suttas) is reorganized, classified systematically, and fleshed out at numerous points. One of these seven books, the Kathavatthu (Points of Controversy), refutes more than two hundred opinions held by other Buddhist schools and in the process reveals the doctrines peculiar to the Theravada. ${ }^{26}$

The Abhidhamma Pitaka serves the monastic community more than the lay, and is specifically useful to the learned and advanced meditators.

It should be noted about the era during which the Tipitaka was transcribed, that the Sutta and the act of preaching had recently achieved ascendancy over practice and the Vinaya for the first time in Theravada tradition. The shift ushered in a nuanced Buddhism that diverged from that which Mahinda had brought. ${ }^{27}$ Despite the transformation, Adikaram assures the academic community that the Pali Canon was kept in pristine adherence to oral records. He writes, “...we may safely consider that the Pali Pitakas on

\footnotetext{
${ }^{24}$ Bareau, Andre, Buddhism, Schools of: Early Doctrinal Schools of Buddhism, 1198.

${ }^{25}$ Ibid., 1198.

${ }^{26}$ Ibid., 1198.

${ }^{27}$ Adikaram, Early History of Buddhism in Ceylon, 78.
} 
the whole depict the Theravada Buddhism of a pre-Mahindian day". ${ }^{28}$ The authenticity and faithfulness of the oral records themselves, however, cannot be validated by history. The Theravada community believes that the purest preservation of the Buddha's teachings has been maintained in Sri Lanka in the Pali Canon, but faith and legend, not history, maintain this credence.

\section{The First Literary Period to Extinction of the Lambhaka Dynasty}

After the Pali Canon had been put to writing, the years between 17 B.C.E. to 66 C.E. constituted what's known as Sri Lanka's First Literary Period. The last book of the Vinaya Pitaka (The Parivara) was finished, and many, if not most, of the Sinhala canonical commentaries date back to this period. ${ }^{29}$ It was also the time when the first Theravada schism occurred on the island. After a Thera by the name of Tissa had been dishonorably discharged from the Mahavihara by the senior monks, Tissa's student, believing the Mahavihara's persecution to have been unjust, established a new sect at the Abhayagiri Vihara monastery. The Abhayagiri School would never again return to the Mahavihara's jurisdiction, though it continued to follow Theravada doctrine. ${ }^{30}$

During the turn of the first millenium, the Anuradhapura Kingdom was politically tumultuous but possessed an astounding functional serenity. The kingdom's ingenious system of hydraulics fostered prosperity and wealth across the island and strengthened the existing feudal system. DeSilva explains that the political turmoil at the time was directly caused by administrative and political structures that were ill-equipped to carry a

\footnotetext{
${ }^{28}$ Ibid., 134.

${ }^{29}$ Adikaram, Early History of Buddhism in Ceylon, 87.

${ }^{30}$ Panabokke, History of the Buddhist Sangha in India and Sri Lanka, 85.
} 
rapidly expanding economy and demands of ambitious rulers. The saving grace was the Mauryan Empire's model of checks and balances which had been applied to rulership since Devanampiya Tissa and which continued to gracefully serve the Anuradhapura Era. Though the players were often changing, the rules remained the same, and each new ruler assumed the responsibility of protecting, purifying, and providing for the Sangha. The Sangha, in return, gave spiritual and legal counsel to the rulers and lay population. ${ }^{31}$

The First Literary Period ended as dynastic feuds over power yielded Anuradhapura's throne to the Lambhaka dynasty in 67 C.E. The Lambhakas would rule for a rare period of political stability until Buddhaghosa's time, some three and a half centuries later. ${ }^{32}$

\section{Bhadantacariya Buddhaghosa and the Visuddhimagga}

Bhadantacariya Buddhaghosa is believed to have been born into a Brahmanic family either near Bodh Gaya, North India, Andhra or Kancipuram, South India, or to have come from Thaton, Burma. ${ }^{33}$ He was converted at a young age to Buddhism by a Thera Revata and given the monastic name, Buddhaghosa, "Tongue of the Buddha". ${ }^{34}$ According to Potter, the future writer made his way through South India before travelling to Sri Lanka in search of the "purist" Theravada tradition around or during the time of King Mahanama (409-431 C.E.), ${ }^{35}$ and Carter confirms Buddhaghosa's specific purpose in

\footnotetext{
${ }^{31}$ DeSilva, A History of Sri Lanka, 17-45.

${ }^{32}$ Ibid., 18.

${ }^{33}$ Carter, John Ross, Encyclopedia of Religion; Buddhaghosa, ed. Lindsay Jones. 2nd ed. Vol. 2. (Detroit: Macmillan Reference USA, 2005), 1074

${ }^{34}$ Prebish, The A to $Z$ of Buddhism, 78.

${ }^{35}$ Potter, Karl H, Encyclopedia of Indian Philosophies. 3 rev ed. (Delhi: Motilal Banarsidass Publishers, 1995), 110.
} 
travelling to the Mahavihara for the study of exegetical Theravada texts. ${ }^{36}$ For the reputation of Anuradhapura in the international Theravada community was unequalled. After all, this was the city of the Mahavihara, guardian of the unadulterated Canon.

According to Robinson and Johnson, when Buddhaghosa arrived at the Mahavihara, he requested permission to translate the Sinhala commentaries into Pali so that they might be accessible to Buddhists outside of Sri Lanka. To determine Buddhaghosa's understanding of the Dhamma and test his skill and worthiness to complete the task, the monks asked him to "compose a treatise on Buddhist practice". Buddhaghosa entitled his treatise Visuddhimagga -in English, The Path of Purity. So impressed were the monks with his work that they not only allowed him to translate the Sinhala commentaries but they also requested that he write commentaries of his own on the books of the Pali Canon. ${ }^{37}$ Before fleeing Sri Lanka during the crumbling political environment that followed Mahanama's death, Buddhaghosa had already translated the Sinhala commentaries and had generated a number of discursive volumes of Canonical exegesis spanning all three Pitakas. ${ }^{38}$

More than all of his later works combined, Buddhaghosa's Visuddhimagga went on immediately to hold the greatest of importance and respect among the international Theravada community. It soon became secondary only to the Tipitaka, and in Sri Lanka and Burma, his commentaries are valued as even more authoritative than the Canon. The status of the Visuddhimagga is of particular interest to this study because for a tradition

\footnotetext{
${ }^{36}$ Carter, Buddhaghosa, 1074.

${ }^{37}$ Robinson and Johnson, The Buddhist Religion: A Historical Introduction, 145.

${ }^{38}$ Carter, Buddhaghosa, 1074.
} 
which identifies itself as having preserved the words of the Buddha with such fidelity and in such purity, there are a surprising number of extraneous infiltrations that scholars have identified in the Visuddhimagga. Robinson and Johnson write,

Buddhaghosa's works demonstrate how much even the most conservative Theravadins in his time had acquired from other elements in the prevailing Buddhist-Brahmanical milieu. For example, they contain views on the supernatural quality of the Buddha which were apparently adopted from the Mahasamghikas. They also refer to "secret doctrines" that the elders would teach only to certain students. More importantly, they drop the canon's emphasis on whole-body breath awareness as the prime form of concentration practice in favor of trance states acquired by staring at objects of various colors, a technique that plays only a peripheral role in the canon. They then define dhyana in terms of these trance states, which by their own admission are virtually impossible to attain through breath awareness. ${ }^{39}$

And these are just some of the more visible textual incursions.

Generally speaking, when he sat down to construct the Visuddhimagga, Buddhaghosa drew from the Pali canonical texts, some postcanonical works, and some Sinhala commentaries. To this list, Adikaram suggests that Dravidian sources and materials from the Puranas ('the Ancients) were also referenced, the latter of which Mrs. Rhys-Davids identifies as "early cultured academics following strict orthodox Buddhism". ${ }^{40}$ Potter then contributes a distinction about the nature of the Visuddhimagga, claiming that "The Visuddhimagga is not a commentary, but a compendious account of Abhidharma Buddhism as a whole, based, according to Buddhaghosa himself, on the (now lost) Sinhalese Atthakathas [commentaries]." ${ }^{\text {41 }}$ Potter's perspective is important because it clarifies the fact that the volume is not Buddhaghosa's commentary, but a collation of

\footnotetext{
${ }^{39}$ Robinson and Johnson, The Buddhist Religion: A Historical Introduction, 145.

${ }^{40}$ Adikaram, Early History of Buddhism in Ceylon, 16.

${ }^{41}$ Potter, Encyclopedia of Indian Philosophies, 111.
} 
existent knowledge, interpretations, and commentaries. His view however, is slightly unusual among scholars for its identification of Abhidhamma Buddhism as the primary subject matter. As it is though, most view the Visuddhimagga as a work inclusive of the entire Tipitaka and existent commentarial works, not just of Abhidhamma; the traditional story maintains that Buddhaghosa's assignment was to collate a treatise on Buddhism so it makes little sense that he would have used only the last and least authoritative book of the canon.

The book itself fills 856 pages in Bhikkhu Ñanamoli's English translation and was divided by Buddhaghosa into three parts which are further divided by twenty three chapters. Tambiah provides an eloquent summary of the contents of the Visuddhimagga and explains the intended relational roles between book and reader:

The Visuddhimagga as an overall composition brilliantly demonstrates the Buddhist central tenet that knowledge and wisdom are joined with practice, and that practice of the meditative exercises provides the experience and understanding of the doctrinal tenets... There is a tripartite ordering to the Visuddhimagga. There is first of all the elucidation of how to systematically cultivate sila, usually translated as "virtue"; next follows the description of the procedures by which samadhi, concentration, is cultivated. Finally, there are the instructions for the cultivation of prajna [vipassana], insight or understanding. There is not so much a linear as a dynamic relationship between the three objectives...the Visuddhimagga's [ultimate] objective is to show the path that leads to purity (suddhi), and as such is primarily addressed to bikkhus...Purification is to be understood as attaining to nibbana which is "devoid of stains."

Keown and Prebish supplement Tambiah's framework by pointing out three topics to which Buddhaghosa gives considerable attention: the Four Noble Truths (1. Suffering exists; 2 . The origin of suffering is attachment; 3 . It is possible to end suffering; 4 . The way to end suffering is the Eightfold Path), pratityasamupada (dependent co-arising of

\footnotetext{
${ }^{42}$ Tambiah, Stanley J, "Purity and Auspiciousness at the Edge of the Hindu Context - in Theravada Buddhist Societies," Journal of Developing Societies. 1 (1): (1985), 96.
} 
phenomena), and the state in which mental functionings cease. ${ }^{43}$ Besides the traditional categorizations of the Visuddhimagga's content, Adikaram also mentions Buddhaghosa's incorporation of a cosmology inherited from the Porana $[\mathrm{sic}] .{ }^{44}$ And so, even though orthodox Theravada Buddhism denies ownership of a cosmology, ironically, a distinct cosmology appears in the Visuddhimagga.

\section{A Note on the English Translator, Bhikkhu Ñanamoli}

Born Osbert Moore in 1905, the former British intelligence officer and BBC correspondent left his job and European lifestyle to travel to Sri Lanka in 1948 in hopes of joining a monastic community. He immediately settled into the Island Hermitage monastery in Dodanduwa and decided to join the order several weeks later. Osbert was 43 when he became formally ordained and given the name Bhikkhu Nanamoli. The monastery he had chosen was internationally respected as following strict and pure observance of Theravada Buddhism. Though a small community, Burmese, Sinhalese, and European visitors of importance often frequented the monastery seeking wisdom, to spend time in meditation or receive education in the Pali texts. ${ }^{45}$

His own Pali lessons were given by Nyanatiloka Mahathera and Soma Thera, monks who taught both classical understanding and interpretation of commentarial idioms. ${ }^{46}$ Possessing great intelligence, a critical eye, and a talent for languages, Ñanamoli began translating Pali texts into English just four years after his arrival. Originally translating

\footnotetext{
${ }^{43}$ Keown, Damien and Charles S. Prebish, Encyclopedia of Buddhism, (New York: Routledge, 2007), 511.

${ }^{44}$ Adikaram, Early History of Buddhism in Ceylon, 20.

45 "The Life of Osbert Moore, Also Known As Ñanamoli Thera." Nanavira Thera Dhamma Page. (Path Press, 2009).

${ }^{46}$ Ibid.
} 
the texts for his personal use, by 1953 he had finished translating the entire

Visuddhimagga, and having gained some attention for his skill and knowledge, was approached in 1955 and asked if he'd be willing to have his translation published. With the editorial help of Nyanaponika Thera and Nyanatiloka Mahathera's German translation of the same work, the first edition of Nanamoli's Visuddhimagga was published a year later in 1956. Nanamoli spent the remaining years of his life at the Island Hermitage translating Pali works and deepening his meditative practice. ${ }^{47}$

\section{Defining Assāsa-passāasa}

As is the difficulty of translation from any one language into another, the translation of Pali into English is not a precise science. Thanks to a handful of Western scholars who have applied diligent study of the Pali language over the last century and a half, some highly accurate Pali-English/English-Pali dictionaries exist. Most notable among them is I.W. Rhys-Davids' and William Stede's Pali Text Society Pali-English Dictionary. However, this too is limited as Bikkhu Nanamoli expresses in the Introduction to his translation of the Visuddhimagga,

In the Visuddhimagga alone the actual words and word meanings not in the P.T.S. Dictionary come to more than 240 . The Dictionary, as its preface states, is 'essentially preliminary'...it leaves out many words even from the Sutta Pitaka, and the Subcommentaries are not touched by it. ${ }^{48}$ Omissions notwithstanding, the P.T.S. Dictionary

\footnotetext{
${ }^{47}$ Buddhaghosa and Bikkhu Nānamoli, The path of purification [Visuddhimagga]. 5th ed. (Kandy: Buddhist Publication Society 1991), xxiii.

${ }^{48}$ Ibid., xlviii.
} 
is an indispensible reference to any study of Theravada Buddhism; it is the most comprehensive of existent dictionaries and an axle of comparison for all others.

In this study, the eleven core terms of inquiry and their definitions were gleaned from four references. They are: (1) The Pali Text Society Pali-English Dictionary; (2) Bikkhu Ñanamoli's Glossary to The Path of Purification; (3) Bikkhu Nyanatiloka's Buddhist Dictionary; and (4) A.P. Buddhadatta's Concise Pali-English Dictionary. Lastly, for purposes of comparison, a collection of common Indian definitions of the Sanskrit term präṇa is given.

The terms and their respective definitions are presented in the same order given in the expository chapter for purposes of consistency. They follow a loose logic of semantic similarity and relationship, beginning with the central term, assãsa-passäsa.

\section{Assāsa-passāsa}

The P.T.S. lists assāsa-passāsa as meaning 'breathing (in and out)', a/the 'sign of life', the 'process of breathing', and 'breath'. ${ }^{49}$ Similarly, Nyanatiloka defines the term to mean 'In and Out-breathing', gives kāya-sankhära as its synonym when meaning 'corporeal or physical functions or formations, vaci-samkhara when referring to verbal functions, and mentions that "In and Out-breathing' forms one of the six aspects of the

\footnotetext{
${ }^{49}$ Rhys-Davids, T. W., and William B. Stede, Pali-english dictionary. 1 lian ed. (Delhi: Motilal Banarsidass Publishers, 1993), 91.
} 
wind element. ${ }^{50}$ Meanwhile Bikkhu Ñanamoli lists assāsa-passāsa simply as 'in-breath and out-breath" ${ }^{, 51}$ while A.P. Buddhadhatta gives mention of it only as 'breath', ${ }^{52}$

\section{Kāya-sankhāra}

The P.T.S. defines kāya-sankhära as 'the material aggregate' and 'substratum of body ${ }^{53}$ Bikkhu Ñanamoli calls it 'bodily formation', but also says it's another name for 'in-breath and out-breath' and therefore a synonym for assāsa-passāsa. ${ }^{54}$ And lastly, A.P. Buddhadhatta provides definitions for kāya and sankhāra separately, 'a heap,' 'collection,' or 'the body' and 'rubbish', respectively. ${ }^{55}$ Constructing a compound term that reflects the first two definitions given, Buddhadhatta's conjunct definition would appear as a phrase close to 'rubbish of the body' or 'the body of rubbish'.

\section{Kāya-viññatti}

Kāya-viññatti is defined by P.T.S. as 'intimation by body, i.e. merely by one's appearance' and curiously mentions that the term "applies chiefly to the begging bikkhu". ${ }^{56}$ Nyanatiloka gives the literal translation to be 'making known' and then goes on to also call it 'intimation', "an Abhidhamma term for Bodily Expression...produced by the co-nascent volition, and [is] therefore, as such, purely physical and not to be

\footnotetext{
${ }^{50}$ Nyanatiloka, Bhikkhu, Corporate Body of the Buddha Educational Foundation, and Nyanaponika Thera, Buddhist dictionary: Manual of buddhist terms and doctrines. 3 rev a enl / it by Nyanaponika ed. (Taipei: Corporate Body of the Buddha Educational Foundation, 1991), 24.

${ }^{51}$ Ñānamoli, The path of purification [Visuddhimagga], 885.

${ }^{52}$ Buddhadatta, Ambalangoda Polvatte, Concise pali-english dictionary. (Colombo: Colombo Apothecaries, 1957).

${ }^{53}$ Rhys-Davids and Stede, Pali-english dictionary.

${ }^{54}$ Ñānamoli, The path of purification [Visuddhimagga], 888.

${ }^{55}$ Buddhadatta, Concise pali-english dictionary.

${ }^{56}$ Rhys-Davids and Stede, Pali-english dictionary, 209.
} 
confounded with Karma, which as such is something mental." ${ }^{57}$ Bikkhu Nanamoli provides three translations: (1) 'body, group, order;' (2) 'the material body;' and (3) 'the mental body-intimation', ${ }^{58}$ and A.P. Buddhadhatta calls kāya-viñnatti 'a heap', 'a collection', 'the body-intimation', and 'information'. 59

\section{Vitthambana}

A Pali term requiring fewer English words in its translation, vitthambhana is defined somewhat differently by each reference in which it is mentioned. P.T.S. gives its definition as 'making firm,' strengthening,' or 'supporting, ${ }^{60}$, Bikkhu Nanamoli calls it 'distension', ${ }^{61}$ and A.P. Buddhadhatta lists its definitions to be 'expansion,' 'putting,' and 'suffusion'. ${ }^{62}$

\section{Vāta}

Vãta is drawn out by P.T.S. to be a complex word. Its etymology is traced to Vedic root word vāta 'to blow' and the Latin relative ventus 'wind'. The Pali-English Dictionary recognizes two distinct types of winds, 'internal' and 'external' and explains, The internal winds...i.e. all kinds of winds (air) or drawing pains (rheumatic?) in the body, from hiccup, stitch and stomach-ache up to breathing. Their complement are the external winds...these are characterized according to direction, dust, temperature, force, height and other causes. ${ }^{63}$

\footnotetext{
${ }^{57}$ Nyanatiloka, Buddhist dictionary : Manual of buddhist terms and doctrines, 196.

${ }^{58}$ Ñānamoli, The path of purification [Visuddhimagga], 888.

${ }^{59}$ Buddhadatta, Concise pali-english dictionary.

${ }^{60}$ Rhys-Davids and Stede, Pali-english dictionary, 621.

${ }^{61}$ Ñānamoli, The path of purification [Visuddhimagga], 894.

${ }^{62}$ Buddhadatta, Concise pali-english dictionary.

${ }^{63}$ Rhys-Davids and Stede, Pali-english dictionary, 607.
} 
Bikkhu Ñanamoli and A.P. Bhuddhadhatta give a simple and mutually identical translation of väta to mean 'air' and/or 'wind'. ${ }^{6465}$

\section{Vāyo}

Väyo receives little mention in Pali-English references, and what mention there is, is vague. P.T. S. merely calls it 'wind, ${ }^{66}$ while Bikkhu Ñanamoli merely calls it 'air', ${ }^{67}$ and A.P. Buddhadhatta's definition merges the two former renderings and says that vāyo is 'the form taken by vāya,' 'the wind,' and 'air'. ${ }^{68}$

\section{$\bar{A}$ nāpāna}

All sources translate ānäpäna similarly. P.T.S. lists the word to mean 'inhaled and exhaled breath' or 'inspiration and expiration'. ${ }^{69}$ Bikkhu Nyanatiloka presents it as a synonym to assāsa-passāsa and therefore kāya-sankhära when he translates it as 'In and Out-breathing, ${ }^{70}$ and both Bikkhu Ñanamoli and A.P. Buddhadhatta agree that ānāpāna means 'breathing'. 7172

\footnotetext{
${ }^{64}$ Ñānamoli, The path of purification [Visuddhimagga], 894.

${ }^{65}$ Buddhadatta, Concise pali-english dictionary.

${ }^{66}$ Rhys-Davids and Stede, Pali-english dictionary, 609.

${ }^{67}$ Naanamamoli, The path of purification [Visuddhimagga], 894.

${ }^{68}$ Buddhadatta, Concise pali-english dictionary.

${ }^{69}$ Rhys-Davids and Stede, Pali-english dictionary, 100.

${ }^{70}$ Nyanatiloka, Buddhist dictionary : Manual of buddhist terms and doctrines, 11.

${ }^{71}$ Naannamoli, The path of purification [Visuddhimagga], 886.

${ }^{72}$ Buddhadatta, Concise pali-english dictionary.
} 


\section{Pāna}

The P.T.S. gives the origin of the Pali word pāna to be the Vedic Sanskrit word prāna 'breath of life'. Its definition is given as 'living being,' 'life,' and 'creature'. ${ }^{73}$ Likewise A.P. Buddhadhatta defines pāṇa as 'life,' 'breath,' and 'living being'. ${ }^{74}$

\section{Viriya}

Another term with Sanskritic roots, P.T.S. gives 'state of a strong man' as the literal translation and elaborates on the definition by giving the supporting descriptive words: 'vigor,' 'energy,' 'effort,' and 'exertion'. ${ }^{75}$ Bikkhu Nyanatiloka defines viriya as 'energy', and gives the slightly different literal translations, 'virility,' 'manliness,' and 'heroism'. He also explains that it is one of the seven Factors of Enlightenment and synonymous to 'Right Effort' on the Eight-fold Path. ${ }^{76}$ Bikkhu Ñanamoli presents it simply as 'energy, ${ }^{77}$ and A.P. Bhuddhadhatta calls it 'vigor,' energy,' 'effort,' and 'strength' ${ }^{78}$

\section{Viñ̄̃̄an}

The P.T.S. definition of viññana provides some surprising translations of this Theravada concept:

[fr. Vi+jña; cp. Vedic vijñana cognition] (as special term in Buddhist metaphysics) a mental quality as a constituent of individuality, the bearer of (individual) life, life-force (as extending also over rebirths), principle of conscious

\footnotetext{
${ }^{73}$ Rhys-Davids and Stede, Pali-english dictionary, 451.

${ }^{74}$ Buddhadatta, Concise pali-english dictionary.

${ }^{75}$ Rhys-Davids and Stede, Pali-english dictionary, 634.

${ }^{76}$ Nyanatiloka, Buddhist dictionary : Manual of buddhist terms and doctrines, 199.

${ }^{77}$ Nānamoli, The path of purification [Visuddhimagga], 894.

${ }^{78}$ Buddhadatta, Concise pali-english dictionary.
} 
life, general consciousness (as function of mind and matter), regenerative force, animation, mind as transmigrant, as transforming (according to individual kamma) one individual life (after death) to the next. ${ }^{79}$

But Bikkhu Nyanatiloka returns to the more traditional orthodox definition when he calls viññāna 'consciousness,' explaining further that it

...is one of the 5 groups of Existence; one of the 4 Nutriments; the third link of the Dependent Origination; the $5^{\text {th }}$ in a sixfold division of elements... it is a flux and does not constitute an abiding mind-substance; nor is it a transmigrating entity or soul. ${ }^{80}$

Bikkhu Ñanamoli keeps Theravadin tradition when he defines viññāna as

'consciousness' or 'cognition, ${ }^{81}$ but A.P. Buddhadhatta follows P.T.S.'s unorthodox suit by calling viñ̃̃āna 'animation' or 'consciousness' ${ }^{82}$

\section{Citta Samutthana}

Only Bikkhus Nyanatiloka and Ñanamoli list citta samutthana as a single term. The former translates it to mean 'mind-produced corporeality ${ }^{83}$ and the latter 'consciousnessoriginated (matter) ${ }^{84}$ The P.T.S. and A.P. Buddhadatta do, however, provide separate definitions for citta and samutthana, and from those, composite definitions can be formed. First is P.T.S.'s translation of citta:

Meaning: the heart (psychologically), i.e. the center and focus of man's emotional nature as well as that intellectual element which inheres in and accompanies its manifestations; i.e. thought. In this wise citta denotes both the agent and that

\footnotetext{
${ }^{79}$ Rhys-Davids and Stede, Pali-english dictionary, 618.

${ }^{80}$ Nyanatiloka, Buddhist dictionary : Manual of buddhist terms and doctrines, 193.

${ }^{81}$ Ñāṇamoli, The path of purification [Visuddhimagga], 894.

${ }^{82}$ Buddhadatta, Concise pali-english dictionary.

${ }^{83}$ Nyanatiloka, Buddhist dictionary : Manual of buddhist terms and doctrines, 41 .

${ }^{84}$ Ñānamoli, The path of purification [Visuddhimagga], 888.
} 
which is enacted...for in Indian Psychology citta is the seat and organ of thought. ${ }^{85}$

When combined with samutthana, 'rising,' 'origination,' 'cause,' or 'arising from, ${ }^{86}$ the definition given by P.T.S. could be said to be 'source of thoughts and thinking'. When A.P. Buddhadatta's definition of citta, 'mind,' 'thought,' 'variegated,' 'manifold,' or 'beautiful', is matched with his definition of samutthana, 'origination' or 'cause', ${ }^{87}$ citta samutthana appears to be 'origin and cause of mental processes, diversity, and beauty'.

\section{Prāna}

Georg Feurstein, author of the Encyclopedia of Religion's entry on prāṇa, presents the six ways in which the Sanskrit word is used. He writes,

The Sanskrit term prāna (from the conjunction of pra and ana, "breathing forth") can signify (1) The Absolute (brahman) as the transcendental source of all life, (2) life in general, (3) the life force or "breath" of life in particular, (4) respiration, (5) air (in secular context only), and (6) the life organs (i.e., the five cognitive senses, the five conative senses, and the sense-related mind, or manas). ${ }^{88}$

Specifically in pre-Visuddhimagga-era works, the Vedas present prāna as the creator's breath, and certain Upaniśads describe prāṇa as ten breaths (vāyu) which flow through an experiential field in and around the physical body called the prānāmaya kośa. ${ }^{89}$

I.K. Taimni, author of The Science of Yoga, asserts that prāna is present on all levels of manifested existence and that it functions as the "intermediary" between matter, energy, consciousness, and mind. ${ }^{90}$

\footnotetext{
${ }^{85}$ Rhys-Davids and Stede, Pali-english dictionary, 266.

${ }^{86}$ Ibid., 687.

${ }^{87}$ Buddhadatta, Concise pali-english dictionary.

${ }^{88}$ Feuerstein, Georg, Encyclopedia of Religion; Präna, ed. Lindsay Jones. 2nd ed. Vol. 11, (Detroit: Macmillan Reference USA, 2005), 7362.

${ }^{89}$ Ibid, 7363.
} 


\section{Assāsa-passāsa in the Visuddhimagga: \\ The Search for a Theravada Ontology}

This chapter brings attention to the use of the above-mentioned eleven words as they appear in Buddhaghosa's Visuddhimagga: assāsa-passāsa ('breathing out and in,' 'sign of life,' 'process of breathing,' and 'breath'), kāya-sankhära (bodily formation or 'inbreath and out-breath'), kãya-viññatti (bodily intimation), vitthambhana (distension), vāta (air, wind), vāyo (air), ānāpāna (breathing), pāṇa (breathing thing, living thing), viriya (energy), viñ̃āạa (consciousness, animation), and citta samutthana (consciousness-originated [matter]). In the chapters following this one, an analytical lens is applied to the findings presented here to determine whether the term assāsa-passāsa betrays an underlying cosmology in the oldest and most traditional Theravada texts. Here, the purpose is exposition of the clues.

The structure of this chapter is straightforward, based on the school of inquiry that maintains the best way to approach any investigation is to present all existing evidence, regardless of interpretation (past or present). In this way, an audience participates with the researcher in the process of combing through information, sees where interpretive decisions are made, and can rest in a more holistic understanding of the subject matter and the author's treatment of it. In the following pages, this chapter takes each of the eleven terms above, presents the sequentially arranged passages of Bikkhu Nanamoli's translation of the Visuddhimagga in which the Pali term has been referenced, and identifies those passages which indicate a potential underlying metaphysical cosmology

\footnotetext{
${ }^{90}$ Taimni, I.K., The Science of Yoga, (Wheaton: The Theosophical Publishing House, 1967), 258.
} 
of 'breath'. To reiterate, the purpose of this chapter is to extricate the concept of 'breath' in the Visuddhimagga.

The exploration begins with assāsa-passāsa ('breathing out and in,' 'sign of life,' 'process of breathing,' and 'breath'), a term for which Bikkhu Nanamoli's index to the Visuddhimagga has referenced only seven passages. At first glance, the pittance of references appears discouraging, but upon review, rich contributions to the search can be found. Assāsa-passāsa first appears in VIII 27:

[Recollection of death] As to the frailty of life: this life is impotent and frail. For the life of beings is bound up with breathing, it is bound up with the postures, it is bound up with cold and heat, it is bound up with the primary elements, and it is bound up with nutriment. ${ }^{91}$

Interestingly enough, Buddhaghosa first introduces the concept of "breath" in a discussion about death. To him, breath is some sort of feeble mechanism sustaining life. It is listed in rank with physical postures, temperature, the primary elements (air, water, earth, fire), and nutriment, a term which is defined under viññāna. Already, the discourse surrounding 'breath' has strong resonance with the discourse surrounding prāna in typical Indian metaphysics.

The second passage appears in VIII:164:

Herein, breathing in long (assasanto) is producing a long in-breath. 'Assäsa is the wind issuing out; passāsa is the wind entering in' is said in the Vinaya Commentary. But in the Suttanta Commentaries it is given in the opposite sense. Herein, when any infant comes out from the mother's womb, first the wind from within goes out and subsequently the wind from without enters in with fine dust, strikes the palate and is extinguished [with the infant's sneezing]. This, firstly, is how assāsa and passāsa should be understood. ${ }^{92}$

\footnotetext{
${ }^{91}$ Buddhaghosa, and Bhikkhu Nānamamoli, The Path of Purification [Visuddhimagga], $5^{\text {th }}$ ed. (Kandy: Buddhist Publication Society, 1991) 231.

92 Ibid., 265.
} 
In a way that partially disrupts the austerity of Theravada expectation, the definition of a 'thing' which is supposed to be no more than a meditative subject or a link in the chain of dependent-origination is given a sort of 'origin story'. Another noteworthy detail in this passage is the description of 'breath' as 'wind', and not just in a generalized sense, but as two distinct types of 'wind'. The subsequent passage, VIII:209, continues to build the term:

The bikkhu should recognize the unmanifest state of the meditation subject and consider thus: 'Where do these in-breaths and out-breaths exist? Where do they not? In whom do they exist? In whom not?'. Then, as he considers thus, he finds that they do not exist in one inside the mother's womb, or in those drowned in water, or likewise in unconscious beings, or in the dead, or in those attained to the fourth jnana, or in those born into a fine-material or immaterial existence, or in those attained to cessation [of perception and feeling]. So he should apostrophize himself thus: 'You with all your wisdom are certainly not [these things]...Those in-breaths and out-breaths are actually existent in you, only you are not able to discern them because your understanding is dull' $(276){ }^{93}$

Here, Buddhaghosa has made two characteristics of 'breath' clear: (1) that it is sometimes unmanifest; and (2) that it exists.

XI:94 introduces an altogether fascinating quality of assāsa-passāsa, namely that it is the only constituent of the live physical body which originates solely in consciousness:

As to how it originated: among the forty-two components beginning with head hairs shown in the detailed treatment of the earth element, etc., the four consisting of gorge, dung, pus, and urine are temperature-originated only; the four consisting of tears, sweat, spittle, and snot are temperature-originated and consciousnessoriginated only. The fire that cooks what is eaten, etc., is kamma-originated only; in-breath and out-breath are consciousness-originated only; all of the rest are of four-fold origination. This is how they should be given attention as to how originated. ${ }^{94}$

\footnotetext{
${ }^{93}$ Ibid., 276.

${ }^{94}$ Ibid., 360 .
} 
We see that tears, sweat, spittle and snot share their origins with temperature and consciousness, and that all the unnamed constituents of the material body share in a fourfold origination mixture, but that "breath' alone is a direct descendant of consciousness. In Indian metaphysics, prana is the intermediary substance between energy, matter, and consciousness. Passage XI:94 seems to indicate a similar uniqueness of assāsa-passāsa.

By coincidence or not, the last two references to assāsa-passāsa are found in the Understanding part of the Visuddhimagga, while the five previous ones appear in Part Two: Concentration. The division appears to be significant, in that the functionality of breath might only be operational in exercises of 'Virtue' and 'Understanding', but not in 'Wisdom' because of Part Three's references' comparatively un-useful contribution to this inquiry. None-the-less, passages from XVIII:6 and XVIII:20 are presented here: ..nine [instances of materiality], that is, the octad-with-nutritive-essence-as-eighth plus sound, in the case of the consciousness-born part [of air consisting] of inbreaths and out-breaths. ${ }^{95}$

...in the in-breaths and out-breaths it is the earth element that has the characteristic of hardness', the feeling that has as its object and experiences its stimulant becomes evident as the feeling aggregate... and the consciousness associated with that as the consciousness aggregate. This is how the immaterial states become evident through feeling. ${ }^{96}$

Though some supporting information about the 'air nature' of sound and some description of elemental influence on the 'breath' is present here, not much more can be gleaned from Part Three: Understanding on assāsa-passāsa.

\footnotetext{
${ }^{95}$ Ibid., 606.

${ }^{96}$ Ibid., 611
} 
Having exhausted assäsa-passāsa's references, we begin with the second term under investigation, viññāna (consciousness, animation), a logical second step considering the relationship purported to exist between 'breath' and 'consciousness'. As will soon become evident, it just so happens that the quantity of material referenced to viññanna in the Visuddhimagga is exactly eight times as much as to assāsa-passāsa. But despite the heavy amount of pages devoted to the presentation of 'consciousness', viññanna is in no way more important to this research than the other ten terms; in fact, many of the following 48 references are inadequate evidence for our purposes.

The first three passages come from Part One of the Visuddhimagga, Virtue. They are presented together for their proximity and similarities:

I:53 But the Ancients (porana) said: 'The eye does not see a visible object because it has no mind. The mind does not see because it has no eyes. But when there is the impingement of door and object he sees by means of the consciousness that has eye-sensitivity as its physical basis. Now (an idiom) such as this is called an "accessory locution" (sasambharakatha). ${ }^{97}$

I:57 ... a visible datum as object comes into the eye's focus, then...eye consciousness with the function of seeing; after that, resultant mind-element with the function of receiving; after that, resultant root-causeless mind-consciousnesselement with the function of investigating; after that, functional root-causeless mind-consciousness-element accomplishing the function of determining arises and ceases. $^{98}$

I:n.14 ...if the eye were to see the visible object, then (organs) belonging to other kinds of consciousness would see too; but that is not so. Why? Because the eye has not thought (acetanatta). And then, if consciousness itself were to see a visible object, it would see it even behind a wall because of being independent of sense resistance (appatighabhavato); but that is not so either because there is no seeing in all kinds of consciousness...So it is as a basis of consciousness that the eye sees. ${ }^{99}$

\footnotetext{
${ }^{97}$ Ibid., 23.

${ }^{98}$ Ibid., 24.

${ }^{99}$ Ibid., 751.
} 
The first discussion of 'consciousness' found in I:53 leaves room to speculate that there could be some sort of intermediary functioning between consciousness, door, and object, enabling 'translation', so to speak, between the three modalities. The second passage presents the chain of causation between an external object and its perception by the mind, and is irrelevant to 'breath' as we'd like to find it, but the third, the note belonging to I:14, explains the emptiness of material constructs and how consciousness, a mechanism acting with some sort of 'higher intelligence' or 'power' operates through these constructs. This passage contributes to a nascent image of the behavior and essence of viñ̄̃āṇa.

In the note to V:5, VII:10, V:28, and the note to V:13, the structure of 'consciousness' continues to receive verbal shape:

V:n.5 In the Suttas the first eight kasinas are the same as those given here, and they are the only ones mentioned in the Dhammasangani (160-203) and Patisambhida (Ps.i,6). The Suttas give space and consciousness as ninth and tenth respectively (M.ii,14-15; D.iii, 268; Netti 89, etc.) But these last two appear to coincide with the first two immaterial states, that is, boundless space and boundless consciousness. (A.ii,45). ${ }^{100}$

VII:10 Formations in sensual becoming are a condition for rebirth-linking consciousness in sensual becoming. And similarly with the rest. ${ }^{101}$

VII:28 And the following things should be constructed in the same way...the six groups of consciousness beginning with eye-consciousness ${ }^{102}$

VII:n.13 Four kinds of nutriment are physical nutriment, contact, mental volition, and consciousness (see M.i,48 and MA.i, 207f.). The seven stations of consciousness are: (1) sense sphere, (2) Brahma's Retinue, (3) Abhassara

\footnotetext{
${ }^{100}$ Ibid., 756.

${ }^{101}$ Ibid., 193.

${ }^{102}$ Ibid., 197.
} 
consciousness are: (1) sense sphere, (2) Brahma's Retinue, (3) Abhassara (Brahma-world) Deities, (4) Subhakinna (Brahma-world) Deities, (5) base consisting of boundless space, (6) base consisting of boundless consciousness, (7) base consisting of nothingness (see D.iii,260). The nine abodes of beings: (1)-(4) as in stations of consciousness, (5) unconscious beings, (6)-(9) the four immaterial states (see D.iii,263). The ten bases are eye, ear, nose, tongue, body, visible object, sound, odor, flavor, tangible object. ${ }^{103}$

We see consciousness as a meditative subject, begin to understand its place within dependent origination, are introduced to the idea that contact, mental volition, and consciousness can serve somewhat like physical nutriment, and that there are seven "stations" of consciousness, 'boundless consciousness' constituting the second (highest) level of those stations.

Sometime later, passage IX:122 identifies the emotive quality 'gladness' as the "Divine Abiding" of unbounded consciousness, that is, Buddhaghosa identifies 'gladness' as a synonym of sorts for viñ̃̃āna:

When he abides in gladness, his mind becomes familiar with apprehending consciousness, since gladness is aroused in him when he sees beings' consciousness arisen in the form of rejoicing over some reason for joy. Then when he surmounts the sphere of boundless space that he has already attained in due course and applies his mind to the consciousness that had as its object the sign of space, [325] his mind enters into it without difficulty. So gladness is the basic support for the base consisting of boundless consciousness, but not for what is beyond that. That is why it is called 'having the sphere of boundless consciousness as the highest'. ${ }^{104}$

The above passage, along with the following two, are interesting, but do not particularly contribute to discovering a metaphysical 'breath' in the text. Passages X:35 and X:50 follow:

$\mathrm{X}: 25$ When he wants to develop the base consisting of boundless consciousness, he must first achieve mastery in the five ways in the attainment of the base

\footnotetext{
${ }^{103}$ Ibid., 774.

${ }^{104}$ Ibid., 317.
} 
consisting of boundless space. Then he should see the danger in the base consisting of boundless space in this way; 'This attainment has fine-material jhana as its near enemy, and it is not as peaceful as the base consisting of boundless consciousness'. So having ended his attachment to that, he should give his attention to the base consisting of boundless consciousness as peaceful, adverting again and again as 'consciousness, consciousness' to the consciousness that occurred pervading that space [as its object]. He should give it attention, review it, and strike at it with applied and sustained thought; [332] but he should not give attention [simply] in this way 'boundless, boundless' ${ }^{105}$

$\mathrm{X}: 50$ And here it is not only perception that is like this, but feeling as well is neither-feeling-nor-non-feeling, consciousness is neither-consciousness-nor-nonconsciousness, and contact is neither contact-nor-non-contact, and the same description applies to the rest of the associated states; but it should be understood that this presentation is given in terms of perception. ${ }^{106}$

Upon reaching XI:1 however, we're presented with further discussion of 'consciousness as nutriment'. The question invoked then is, what is the 'nutriment' and how and to whom/what is consciousness bestowing it?

[341] Now comes the description of the development of the perception of repulsiveness in nutriment, which was listed as the 'one perception' next to the immaterial states (Ch. III, 105). Herein; it nourishes (aharati, lit. brings on), thus it is nutriment (ahara, lit. bringing on). That is of four kinds as physical nutriment, nutriment consisting of contact, nutriment consisting of mental volition, and nutriment consisting of consciousness. ${ }^{107}$

Then in XI:107, the mysteriously operating roles of internal elements are contrasted, with respect to their interactions with consciousness, to the external elements, which are apparently "of the opposite kind". This finding bears on the concept of assāsa-passāsa, lending more information as to what makes assãsa different from passāsa and their relationship to 'air' and 'wind':

\footnotetext{
${ }^{105}$ Ibid., 325-26.

${ }^{106}$ Ibid., 332.

${ }^{107}$ Ibid., 337.
} 
As to distinction between internal and external: the internal elements are the [material] support for the physical bases of consciousness, for the kinds of intimation, and for the material faculties. They are associated with postures, and they are of fourfold origination. The external elements are of the opposite kind. ${ }^{108}$

In the chapter on supernatural powers, the note on XII:21 makes an even bolder assertion about 'consciousness':

'This [the going of consciousness] should be regarded as implying that there is no sex or life faculty in it either' (Pm. 398) ${ }^{109}$.

More than any other comment thus far, the note above gives momentum to this search.

Here, Buddhaghosa clearly states that consciousness is life-less and non-generative. If there is some "life force" being discussed in the Visuddhimagga, we can be sure it is not viñ̄nāṇa.

When Chapter Nine takes up the topic of 'consciousness', it's primarily to deconstruct any further aggrandizing illusions one might have about it. Viññaña appears five times in this chapter:

XIV:3 For though the state of knowing (janana) in a particular mode separate from the modes of perceiving (sanjanana) and cognizing (vijanana). [437] For though the state of knowing (janana-bhava) is equally present in perception (sanna), in consciousness (vinnana), and in understanding (panna), nevertheless perception is only the mere perceiving of an object as say 'blue' or 'yellow'; it cannot bring about the penetration of its characteristics as impermanent, painful, and not-self. Consciousness knows the objects as blue and yellow, and it brings about the penetration of its characteristics, but it cannot bring about, by endeavoring, the manifestation of the [supramundane] path. ${ }^{110}$

XIV:6 Hence the venerable Nagasena said... 'The difficult thing, O King, done by the Blessed One was the defining of the immaterial states of consciousness and

\footnotetext{
${ }^{108}$ Ibid., 363

${ }^{109}$ Ibid., 801.

${ }^{110}$ Ibid., 435-36.
} 
its concomitants, which occur with a single object, and which he declared [the five aggregates]' (Miln. 87). ${ }^{111}$

XIV:81 ... whatever has the characteristic of cognizing, all taken together, as the consciousness aggregate. ${ }^{112}$

XIV:129 Since there is no consciousness dissociated from perception, perception therefore has the same number of divisions as consciousness [that is to say, eighty-nine]. ${ }^{113}$

XIV:214 Any kind of consciousness whatever...far or near: this is called the consciousness aggregate...Any kind of consciousness whatever...far or near, this is subject to cankers and liable to the clinging. ${ }^{114}$

Again, the purpose of these passages is to expose how fallible consciousness is and to show the infinitely more capable 'pañña' (understanding). The next references do not appear until Chapter Fifteen, and from then until Chapter Twenty, viññanna is categorized and dissected in many ways and presented in its place in the twelve-fold rendering of dependent origination:

$\mathrm{XV}: 9 . .$. why is 'twelve-bases' said instead of simply 'mental-data base'? It is for the sake of defining door-cum-object for the arising of the six consciousness groups. And here they are stated as twelve since this is how they are classed when so defined. [483]. ${ }^{115}$

$\mathrm{XV}: 27$ The sense-desire element is either merely the mental data element, according as it is said 'Herein, what is the sense-desire element? It is the thought, applied thought,... wrong thinking, that is associated with sense-desires' (Vbh.86), or it is the eighteen elements, according as it is said: 'Making the Avici hell the lower limit and making the Paranimmitavasavatti deities the upper limit, the aggregates, elements, bases, materiality, feeling, perception, formations, and

\footnotetext{
${ }^{111}$ Ibid., 436-37.

112 Ibid., 453.

${ }^{113}$ Ibid., 464.

114 Ibid., 483.

${ }^{115}$ Ibid., 489.
} 
consciousness that are in this interval, that belong here, are included here: these are called the sense-desire element' (Vbh. 86). [487]. ${ }^{116}$

XVII:2 Herein, firstly, it is the states beginning with ignorance that should be understood as dependent origination...'With ignorance as condition there are [volitional] formations; with formations as condition, consciousness; with consciousness as condition, mentality-materiality; with mentality-materiality as condition, the six-fold base; with the six-fold base as condition, contact; with contact as condition, feeling; with feeling as condition, craving; with craving as condition, clinging; with clinging as condition, becoming; with becoming as condition, birth; with birth as condition there is ageing-and-death, and sorrow, lamentation, pain, grief, and despair; thus there is the arising of this whole mass of suffering.' (S.ii, 1$){ }^{117}$

While passage XVII:2 shows 'consciousness' as the product of volitional formations and the cause of mentality-materiality, passage XVII:48 and 51 describe 'cognizing' to be the essential characteristic of consciousness:

XVII:48 It cognizes (vijanati), thus it is consciousness (viññāna-see M.i,292). ${ }^{118}$

XVII:51 Consciousness has the characteristic of cognizing. Its function is to go before (see Dh.1). It manifests itself as rebirth-linking. Its proximate cause is formations; or its proximate cause is the physical-basis-cum-object...Contact has the characteristic of touching. Its function is impingement. It manifests itself as coincidence [of internal and external base and consciousness]. ${ }^{119}$

XVII:54 returns to the process of categorizing consciousness and its kinds, and (as warned) a number of unusable conversations and some poetry on the subject follow:

XVII:54 Consciousness is singlefold as mundane (Dhs.,p.3), resultant (Dhs.,p.1), and so on. It is twofold was with root-cause and without root-cause and so on. It is threefold as included in the three kinds of becoming; as associated with the three kinds of feeling; and as having no root cause, having two root causes, and having

\footnotetext{
${ }^{116}$ Ibid., 483.

${ }^{117}$ Ibid., 525.

118 Ibid., 537.

${ }^{119}$ Ibid., 538 .
} 
three root causes. It is fourfold and fivefold [respectively] according to generation and destiny. ${ }^{120}$

XVII:120f. So all the thirty-two mundane resultant consciousnesses ((34)-(65)) are included by these six kinds of consciousness. But the supramundane kinds do not belong to the exposition of the round [of becoming], and so they are not included. ${ }^{121}$

XVII:294 'Here [in the present becoming] there is rebirth-linking, which is consciousness, there is descent [into the womb], which is mentality-materiality; there is sensitivity, which is sense-base; there is what is touched, which is contact; there is what is felt, which is feeling; thus these five things here in the [present] rebirth-process becoming have their conditions in kamma done in the past' (Ps.i,52). ${ }^{122}$

XVIII:8 'The supramundane kinds of consciousness, however, are not discernable either by one who is practicing pure insight or by one whose vehicle is serenity because they are out of their reach. Taking all these immaterial states together under the characteristic of 'bending', he sees them as 'mentality'. ${ }^{123}$

XVIII:11 The consciousness that occurs with the eye as its support and contingent upon a visible datum is called 'eye-consciousness element' [and likewise with the ear and so on]. In this way the two sets of five consciousnesses are the five 'consciousness elements'... So all the eighty-one kinds of mundane consciousness make up seven kinds of consciousness element; and the contact, etc., associated therewith are the mental-data element. So ten-and-a-half elements are materiality and seven-and-a-half elements [590] are mentality. This is how one [meditator] defines mentality-materiality by means of the eighteen elements. ${ }^{124}$

XVIII:13 Another defines it more briefly that that by means of the aggregates...He defines the feeling that arises together with the 81 kinds of mundane consciousness as the 'feeling aggregate'...the formations associated therewith as the 'formations aggregate', and the consciousness and the 'consciousness aggregate'... he defines mentality-materiality by means of the five aggregates $^{125}$.

\footnotetext{
${ }^{120}$ Ibid., 539.

${ }^{121}$ Ibid., 556.

122 Ibid., 598.

${ }^{123}$ Ibid., 607.

${ }^{124}$ Ibid., 608.

${ }^{125}$ Ibid., 609.
} 
formations aggregate. .. This is how the immaterial states become evident through consciousness. ${ }^{126}$

$\mathrm{XIX}: 13$ 'Here [in the present becoming] there is rebirth-linking, which is consciousness..., 127

XIX:23 Just as eye-consciousness comes next

Following on mind element,

Which, though it does not come from that,

Yet fails not next to be produced,

So too, in rebirth-linking, conscious

Continuity takes place;

The prior consciousness breaks up,

The subsequent is born from that.

They have no interval between,

Nor gap [that separates the two];

While naught whatever passes over,

Still rebirth-linking comes about. ${ }^{128}$

XX:6 Any material whatever, whether past, future or present, internal or external, gross or subtle, inferior or superior, far or near-he defines all materiality as impermanent: this is one kind of comprehension. He defines it as painful: this is one kind of comprehension. He defines it as not-self: this is one kind of comprehension. ${ }^{29}$

XX:9 Herein, the abbreviation, 'The eye... (etc)...Ageing-and-death', should be understood to represent the following sets of things elided: [24 sets follow] ${ }^{130}$

XX:31 Consciousnesses thirty-two,

And twenty-six, and nineteen too,

Are reckoned to give birth to matter,

Postures, also intimation;

Sixteen kinds of consciousness

Are reckoned to give birth to none.

\footnotetext{
${ }^{126}$ Ibid., 611 .

${ }^{127}$ Ibid., 619.

${ }^{128}$ Ibid., 624.

${ }^{129}$ Ibid., 627-28.

${ }^{130}$ Ibid., 629.
} 
Are reckoned to give birth to matter, Postures, also intimation;

Sixteen kinds of consciousness

Are reckoned to give birth to none.

And those herein that do give rise to materiality do not do so at the instant of their presence or at the instance of their dissolution, for consciousness is weak then. But it is strong at the instant of arising. Consequently it originates materiality then with the pre-nascent physical basis as its support. ${ }^{131}$

Finally here in XX:31, more material appears which is contributive to the search for cosmology. In this passage, actually what is first most notable is a contradiction to passage XII:21's assertion that 'consciousness' is non-generative. Here, thirty-two types of consciousnesses are said to "give birth" to matter. So which is it? Is consciousness creative or not? Also of interest in this passage is the degree to which consciousness has strength in the materiality it "inhabits". We see that at the moment of a newly arisen material 'thing' - or being, I suppose-it will have much stronger consciousness than one which is midway through or toward the end of its existence.

$\mathrm{XX}: 43$ and 78 return to the work of categorizing the parts and types of consciousness, XX:94 describes the qualities of consciousness generation and change, and the remaining passages are all roadmaps through consciousness for the advanced meditator on his way to nibanna:

$\mathrm{XX}$ :43 That same [nineteen-fold arising of consciousness is generated] as lifecontinuum as well, starting from the consciousness next to rebirth-linking consciousness, and as death consciousness at the termination of the life span. And when it is of the sense sphere, and the object in the six doors is a vivid one, it is also generated as registration. ${ }^{132}$

\footnotetext{
${ }^{131}$ Ibid., 636-37.

132 Ibid., 639.
} 
XX:78 According to the Discourse on the Noble Ones' Heritages, however, he is said to 'comprehend by groups' when by means of a subsequent consciousness he comprehends as 'impermanent, painful, not-self' that consciousness which occurred [comprehending] materiality as 'impermanent, painful, not-self' in the seven instances of the material septad. ${ }^{133}$

XX:94 Present feeling...perception...formations...consciousness...eye...(etc.)... Present becoming is born [becoming]; the characteristic of its generation is rise, the characteristic of its change is fall, the contemplation is knowledge'(Ps.i,54). ${ }^{134}$

XXI:11 Consciousness with feeling...perception...formations...consciousness... with eye as its object... (etc.- - see Ch. XX, 9) ...with ageing-and-death as its object... Relinquishing, he abandons grasping. ${ }^{135}$

XXI:56 Materiality...Feeling...perception...formations...consciousness...eye... (etc., see Ch.XX, 9)...ageing-and-death has no core... of permanence, or core of lastingness, or core of pleasure, or core of self, or as far as concerns what is permanent, or what is lasting or what is eternal, or what is not subject to change. ${ }^{136}$

XXII:36 'Four roads to power: the road to power consisting in zeal, the road to power consisting in energy, the road to power consisting in [natural purity of] consciousness, the road to power consisting in inquiry' (Vbh.223). These are supramundane only. ${ }^{137}$

XXII:42 ...energy is the one 'in nine ways' since it has four right endeavors, a road to power, a faculty, a power, and enlightenment factor, and a path factor. $[681] .{ }^{138}$

XXII:53 The perversions are the three, namely, the perversion of perception, of consciousness, and of view, which occur apprehending objects that are impermanent, painful, not-self, and foul (ugly), as permanent, pleasant, self, and beautiful. ${ }^{139}$

\footnotetext{
${ }^{133}$ Ibid., 648.

${ }^{134}$ Ibid., 652.

${ }^{135}$ Ibid., 664.

${ }^{136}$ Ibid., 677

${ }^{137}$ Ibid., 703.

${ }^{138}$ Ibid., 705 .

${ }^{139}$ Ibid., 708.
} 
XXIII:13 So the emergence from the attainment of fruition comes about in him when he brings to mind whatever is the object of the life-continuum. ${ }^{141}$

XXIII:18 What is the attainment of cessation? It is the non-occurrence of consciousness and its concomitants owing to their progressive cessation. ${ }^{142}$

XXIII:22 Contemplation of impermanence ... in consciousness is insight as a power... Contemplation of relinquishment in consciousness is insight as power. ${ }^{143}$

XXIII:30 Being wearied by the occurrence and dissolution of formations, they attain it thinking, 'Let us dwell in bliss by being without consciousness here and now and reaching the cessation that is nibanna'. ${ }^{144}$

The process picks up again from the beginning with a third term of inquiry, citta samutthana (consciousness-originated [matter]). It is a much less-frequent term in the Visuddhimagga than viññana, but one that yields a significant amount of insight into the potentially profound idea of assāsa-passāsa. Though not explicit in its translation, citta samutthana refers directly to assäsa-passāsa because of its unique quality of being 'consciousness-originated'. The first discussion with this term appears in the note to passage VIII:54:

Hence he said "And that is not by following after the beginning, middle and end". "The navel is the beginning" because of their first arising there. For the notion of a beginning (adi cinta) is here in the sense of first arising, not in the sense of just arising [once only]. For they actually go on arising throughout [the whole length] from the navel to the nose-tip; and wherever they arise, there in that same place they dissolve, because there is no going (movement) of dhammas. The ordinary term "motion" (gatisamanna) refers to successive arisings in adjacent locations (desantaruppatti) according to conditions. "The heart is the middle": near the heart, just above it is the middle. "The nose tip is the end": the place where the

\footnotetext{
${ }^{141}$ Ibid., 729.

${ }^{142}$ Ibid., 731 .

${ }^{143}$ Ibid., 732.

${ }^{144}$ Ibid., 734.
} 
(desantaruppatti) according to conditions. "The heart is the middle": near the heart, just above it is the middle. "The nose tip is the end": the place where the nostrils are is the end; that is the limit of the application of the ordinary term "inbreaths and out-breaths", for it is accordingly that they are called "consciousnessoriginated", there being no production externally of what is consciousnessoriginated' (Pm.268). ${ }^{145}$

Buddhaghosa gives a fairly cryptic account of this citta samutthana as it travels through the physical body. It seems that he is saying that breath (or dhammas...it is difficult to tell) actually arises inside of the lungs and is not an external substance or production at all. This would mean that assāsa-passāsa is irreconcilably different from atmospheric air, and that if it is a 'vital force' of sorts, it is internal to beings and not external.

The next passage is no less interesting and also happens to be the only passage in the Visuddhimagga referring to kāya-viññatti (bodily intimation). In XIV:61, Buddhaghosa demonstrates how consciousness generates air, which in turn causes bodily intimation, which then inspires bodily excitement, and which finally turns into intention:

Bodily intimation is the mode (conformation) and the alteration (deformation) in the consciousness-originated air element that causes the occurrence of moving forward, etc., which mode and alteration are a condition for the stiffening, upholding, and moving of the connascent material body. [448] Its function is to display intention. It is manifested as the cause of bodily excitement. Its proximate cause is the consciousness-originated air element. But it is called 'bodily intimation' (kaya-vinnatti) because it is the cause of the intimating (vinnapana) of intention by means of bodily excitement, and because it is itself inimitable though the body, in other words, through that bodily excitement. Moving forward etc., should be understood to occur owing to the movement of the [kinds of matter] that are temperature-born, etc., which are interlocked with the consciousness-born kinds moved by that [intimation]. (See Dhs. 636). ${ }^{146}$

This passage also shows, for the first time, the interaction between different sorts of matter in the example given in the last sentence. Somewhat simplistically, we are shown

\footnotetext{
${ }^{145}$ Ibid., 785-86.

${ }^{146}$ Ibid., 448.
} 
how physical movement of and in our body owes to the interconnection between consciousness-originated and temperature-born materials. But if 'breath' is only consciousness-born, then is the movement of 'breath' the product of this exchange or is it organic to itself?

The next passage fortunately doesn't complicate the question further, but it does not give more lucidity to the search either:

XIX:9 Herein it is only when it is past that kamma is a condition for kammaoriginated materiality; consciousness is a condition, when it is arising, for consciousness-originated materiality. Temperature and nutriment are conditions at the instant (moment) of their presence for temperature-originated and nutrientoriginated materiality'. ${ }^{147}$

The same cannot be said for the last passage on citta samutthana, XX29, which only provokes the question, what is 'kamma-resultant consciousness'?

What is originated by consciousness that has kamma as its condition is materiality originated by kamma-resultant consciousness. ${ }^{148}$

Having summarily covered citta samutthana and kāya-viññatti, let us move on to the sixth term in question, kāya-sankhāra (bodily formation or 'in-breath and out-breath'), a similar concept to both assāsa-passāsa and citta samutthana. The first passage with kāya-sankhāra is VIII:175:

He trains thus: 'I shall breathe in...shall breathe out tranquilizing the bodily formation', he trains thus: 'I shall breathe in, shall breathe out tranquilizing, completely tranquilizing, stopping, stilling, the gross bodily formation'. ${ }^{149}$

\footnotetext{
${ }^{147}$ Ibid., 618-19.

${ }^{148}$ Ibid., 635.

${ }^{149}$ Ibid., 267.
} 
The description given here is of an intimate relationship between intention (as spoken of in XIV:61), breath, and the physical body. It appears that mental intention conjoined with awareness of the breath produces a tranquilized body. Though a more thorough explanation of the process would be strong, if not concrete, evidence of a metaphysical force exchanged through consciousness and breath and distributed throughout the body, this passage communicates the same idea, just in a less explicit way.

Passage XVII:61 deals with some more cryptic subject matter. It appears that Buddhaghosa is identifying kāya-sankhāra as being synonymous with bodily volition, as being caused by ignorance, and causative to both good and bad merit:

...bodily formation is bodily volition [and] ... at the moment of the accumulation of the kamma the formations of merit, etc., occur in these [three] kamma doors. For the eight sense-sphere profitable and twelve unprofitable volitions, making twenty, are the bodily formation when they occur in the body door and produce bodily intimation...like direct knowledge volition, so also volition connected with agitation is not included; therefore that too should not be included as a condition for [rebirth-linking] consciousness. However, all these have ignorance as their condition...ignorance can be understood as condition for formations of merit and so on. ${ }^{150}$

Jumping across subjects, the next passage to deal with the term does so in reference to the state of breath in the body when a meditator has attained the fourth jhana:

XXIII:24 In one who has attained the fourth jhana the bodily formations consisting in in-breaths and out-breaths are quite tranquilized. ${ }^{151}$

And similarly, passage XXIII:51 discusses the difference between such a meditative state and death:

'When a bikkhu is dead, friend, has completed his term, his bodily formations have ceased and are quite still...his life is exhausted, his heat has subsided, and

\footnotetext{
${ }^{150}$ Ibid., 541.

${ }^{151}$ Ibid., 732.
} 
his faculties are broken up. When a bikkhu has entered upon the cessation of perception and feeling, his bodily formations have ceased and are quite still... his life is unexhausted, his heat has not subsided, his faculties are quite whole' $\left(\right.$ M.i,296). ${ }^{152}$

Although the qualities of a dead person are usually taken for granted without much discussion, this passage raises a problematic distinction. It notes that a person in the fourth jhana will have ceased (or nearly ceased) breathing, but is still warm and living. What does this mean for: (a) the state of the fourth jhana; and (b) the role of breath? The above question aside for the time being, six terms still remain to be given attention. The first of these (and the $6^{\text {th }}$ overall) is vitthambhana (distension). Appearing in only one chapter of the Visuddhimagga under Part Two: Concentration, 'distension' is first presented in XI:37:

Air (vayo) [is definable] as blowing (vayana). The airy (vayo-gata) is what is gone (gata), in the way already described, among the kinds of air. What is that? It is what has the characteristic of distension. Up-going winds: winds (forces) mounting upwards that cause the occurrence of vomiting, belching, and so on. Down-going winds: winds (forces) descending downward that expel excrement and urine. Winds in the belly: winds (forces) outside the bowels. Winds in the bowels: winds (forces) inside the bowels. Winds that course through all the limbs: winds (forces) that produce flexing, extending, etc., and are distributed over the limbs and the whole body by means of the network of veins (nerves). In-breath: wind in the nostrils entering in. Out-breath: wind in the nostrils issuing out. And here the first five are of fourfold origination. In-breath and out-breath are consciousness-originated.[351] $]^{153}$

It is nearly impossible to read the description of 'bodily winds' given in XI:37 and not to see the similarities in description to the types of prāna said to move throughout the human body in Indian metaphysics. To understand 'distention' better though, we turn out attention to XI:84, 89,93 , and the note to 24 :

\footnotetext{
${ }^{152}$ Ibid., 738.

${ }^{153}$ Ibid., 346.
} 
$\mathrm{XI}: 84$...the characteristic of distension, which is there too, as the air element...As he defines them in this way the element become evident to him. As he adverts to them and gives attention to them again and again access concentration arises in him in the way already stated. ${ }^{154}$

$\mathrm{XI}: 89$ By particles: in this body the earth element taken as reduced to fine dust and powdered to the size of the smallest atom might amount to an average dona measure full; and that is held together by the water element measuring half as much. Being maintained by the fire element, and distended by the air element, it does not get scattered or dissipated. Instead... it arrives at the alternative states of the female and male sex, etc., and manifests smallness, bigness, length, shortness, toughness, rigidity, and so on. ${ }^{155}$

XI:93 The air element has the characteristic of distending. Its function is to cause motion. It is manifested as conveying. ${ }^{156}$

XI:n.24 Vitthambhana - 'distension': the word most usually employed to describe the air element. It is often rendered by 'supporting', a word earmarked here for nissaya. The twofold function of the air element is (a) to uphold (sandharana) by distending (vitthambhana) and preventing collapse (92), and (b) to move (samudirana) or more strictly, cause the appearance of motion (calana, see n.37). In Ch. XIV, 61 it is said to cause thambhana, rendered by 'stiffening'; but there is the description of the earth element as thaddha (e.g. 39; pp. of thambhati, from which the n. thambhana comes) rendered by 'stiffedness'. It may also be noted that the word sandharana (upholding) is used to describe both the earth element (Ch. XIV, 47) and the air element (Ch. XIV, 61). ${ }^{157}$

The evidence of a sort of animating life-force within the human body is most obvious in these writings on vitthambhana. These descriptions will feature prominently in the following chapter on analysis.

Continuing to peruse the text for the next term, väta (air, wind), we find that the subject matter connects closely with vitthambhana since vāta is the force behind

\footnotetext{
154 Ibid., 358.

155 Ibid.

${ }^{156}$ Ibid., 360.

${ }^{157}$ Ibid., 796-97.
} 
vitthambhana. The purpose of the first passage here is to act as a counterargument against the Buddha's teachings, and should be read as such:

VIII: 182 '[Objection:] So then, he trains thus: "I shall breathe in tranquilizing the bodily formation"; he trains thus: "I shall breathe out tranquilizing the bodily formation"; that being so, there is production of awareness of wind, and there is no production of in-breaths and out-breaths, and there is no production of mindfulness of breathing, and there is no production of concentration through mindfulness of breathing, and consequently the wise neither enter into nor emerge from that attainment. ${ }^{158}$

The second and last passage on passage on vāta is an excerpt from a cosmological discussion at the end of Part Two: Concentration. It is clear that there is more to this description of air than meditative instructions:

XIII:42 Then the winds (forces) beneath and all around that water rise up and compact it and round it, like water drops on a lotus leaf. How do they compact the great mass of water? By making gaps; for the wind makes gaps in it here and there. ${ }^{159}$

The next term, $v \bar{a} y o$ (air) is frequently interchangeable with vāta, although the subtleties of meaning distinguishing the two can sometimes be of utmost importance.

However, as is the case with the first passage below, the terms are synonymous. Here too, Buddhaghosa speaks of the cosmological eons marked by the world's creation and destruction:

XIII:30 Herein, there are three kinds of contraction: contraction due to water, contraction die to fire, and contraction due to air (see M. Sutta 28). Also there are three limits to the contraction; the Abhassara (Streaming-radience) Brahmaworld, that of the Subhakinha (Refulgent-glory), and that of the Vehapphala (Great-fruit). When the aeon contracts owing to fire, all below the Abhassara [Brahma-world] is burnt up by fire. When it contracts owing to water, it is all dissolved by water up to the Subhakinha [Brahma-world]. When it contracts

\footnotetext{
${ }^{158}$ Ibid., 269.

${ }^{159}$ Ibid., 439.
} 
owing to air, it is all demolished by wind up to the Vehapphala [Brahmaworld]. ${ }^{160}$

Like so many of the references before, this too is interesting, but disconnected from the primary goal of this research.

XIII:59 The occasion when the aeon is destroyed by air should be treated in the way already described beginning with 'first of all great cloud heralding the aeon's destruction appears...'(32) ${ }^{161}$

Passage XV:39 returns closer to the topic at hand but is still fairly obscure:

Nose-consciousness arises due to nose, odor, air, and attention...Mindconsciousness arises due to life-continuum mind, mental datum, and attention. ${ }^{162}$

The $9^{\text {th }}$ term, viriya (energy), starts a new discussion, swerving away from the thread of bodily winds and air that has been predominant for some pages. The reason this term is included in an inquiry into 'breath' is that 'energy' is said to be either closely related to or descriptive of 'life-force', the subject of this search. Like the section on viññanna, there are a number of passages presented here on the subject of energy, but not all of them have significant contributions to make to the search for a metaphysical breath-those which do not will be glossed over. The initial series of passages are examples of those which do not serve the purpose, but which I feel must be presented; the first four found in Part One:

Virtue, and the last two in Part Two: Concentration:

I:18 Virtue as restraint should be understood here as restraint in five ways: restraint by the rules of community (patimokkha), restraint by mindfulness, restraint by knowledge, restraint by patience, and restraint by energy" (10). And

\footnotetext{
${ }^{160}$ Ibid., 410.

${ }^{161}$ Ibid., 416.

${ }^{162}$ Ibid., 495.
} 
what is called 'restraint by energy' is that given in the way beginning 'He dies not endure a thought of sense desires when it arises' (M.,11). ${ }^{163}$

I:26 ...fulfilling a training precept announced by the Blessed One thus 'This should be done' is keeping...Herein, keeping is accomplished by faith and energy. ${ }^{164}$

I:33 In the first of the triads the inferior [kind of virtue] is produced by inferior zeal, [purity of] consciousness, energy, or inquiry; the medium is produced by medium zeal, etc.; the superior, by superior (zeal, and so on). ${ }^{165}$

I:111 ...livelihood purification is to be undertaken by means of energy. For that is accomplished by energy, because the abandoning of wrong livelihood is effected in one who has rightly applied energy. Abandoning, therefore, unbefitting wrong search, this should be undertaken with energy by means of the right kind of search consisting in going on alms round, etc., avoiding what is of impure origin as though it were a poisonous snake, and using only requisites of pure origin. ${ }^{166}$

III:24 If a bikkhu obtains concentration, obtains unification of mind...by making energy predominant...this is called concentration due to [energy] (Vbh. 21619).

IV:45f. Maintaining balanced faculties is equalizing the five faculties of faith and the rest. For if his faith faculty is strong and the others weak, then the energy faculty cannot perform its function of exerting...this is illustrated by the story of the Elder Vakkali (S.iii, 119). ${ }^{168}$

Then, here in passage IV:51, the Buddha is giving meditation instructions by likening the state of mind to a damp or arid fire. Although the anecdote is a metaphor, the description of energy as a commodity that can be stored, released, fed, or depleted sounds reminiscent of the concept of prāna:

\footnotetext{
${ }^{163}$ Ibid., 11.

${ }^{164}$ Ibid., 15.

${ }^{165}$ Ibid., 17.

${ }^{166}$ Ibid., 40 .

${ }^{167}$ Ibid., 90.

${ }^{168}$ Ibid., 128
} 
IV:51 When his mind is slack with over-laxness of energy, etc., then instead of developing the three enlightenment factors beginning with tranquility, he should develop those beginning with investigation-of-states. For this is said by the Blessed One: 'Bhikkhus, suppose a man wanted to make a small fire burn up, and he put wet grass on it, put wet cowdung on it, put wet sticks on it, sprinkled it with water, and scattered dust on it, would that man be able to make the small fire burn up? [131] -No, venerable sir.-So too, bikkhus, when the mind is slack, that is not the time to develop the tranquility enlightenment factor, the concentration enlightenment factor or the equanimity enlightenment factor. Why is that?

Because a slack mind cannot well be roused by those states. When the mind is slack, that is the time to develop the investigation-of-states enlightenment factor, the energy enlightenment factor and the happiness enlightenment factor. Why is that? Because a slack mind can well be roused by those states. $\left(\right.$ S.v, 112) ${ }^{169}$

Likewise, passage IV:72 depicts energy, as it is directed to the mind during meditation as something like water-too much and a person drowns, too little and the person dies of thirst - but just the right amount of water will allow one to float indefinitely. Water has often been likened to prāna, a flowing sort of force that travels through conduits which direct its use throughout the body and 'mind'. It seems a snapshot of this image appears below:

IV:72 Just as in these five similes, so too when the sign arises, one bikkhu forces his energy thinking 'I shall soon reach absorption'. Then his mind lapses into agitation because of his mind's over-exerted energy and he is prevented from reaching absorption. Another who sees the defect in over-exertion slack off his energy, thinking 'What is absorption to me now?'. Then his mind lapses into idleness because of his mind's too lax energy and he too is prevented from reaching absorption. Yet another who frees his mind from idleness even when it is only slightly idle and from agitation when only slightly agitated, confronting the sign with balanced effort, reaches absorption. One should be like the lastnamed. ${ }^{170}$

Passage IV:113 simply reaffirms the ultimate result of 'right energy':

IV:113 'Of the first jnana satisfaction is the end": how many characteristics has the end? The end has four characteristics. The satisfaction in the sense that there

${ }^{169}$ Ibid., 129.

${ }^{170}$ Ibid., 135. 
was non-excess of any of the states arisen therein, and the satisfaction in the sense that the faculties had a single function, and the satisfaction in the sense that the appropriate energy was effective, and the satisfaction in the sense of repetition, are the satisfaction in the end of the first jnana.' (Ps.i,167-68). ${ }^{171}$

And several passages are devoted to categorizing this 'energy'. One important term that arises is 'effort', a word that includes a handful of energy's characteristics along with some additional contributing aspects:

XVI:1 The 'faculties' listed next to the elements (Ch. XIV, 32) are the twenty-two faculties [one of which is the]...energy faculty...

XVI:86 The thirty-six modes of behavior of craving are included in the truth of origin... The term right effort includes fourfold right endeavor, the energy faculty, energy power, and energy enlightenment factor. ${ }^{173}$

XVII:72 ...it is the four states called zeal, [purity of] consciousness, energy, and inquiry, that should be understood as predominance condition; but not simultaneously, for when consciousness occurs with emphasis on zeal and putting zeal foremost, then it is zeal and not the others that is predominant. So with the rest... 'When any states, as states of consciousness and consciousnessconcomitants, arise by giving importance to any states, these [latter] states are a condition, as predominance condition, for those [former] states' $(\mathrm{Ptn} .1,2) .{ }^{174}$

The discussion of viriya returns to the ideal of balance in XX 119, and the acquisition of this perfectly harmonizing energy is attributed to the development of insight:

Exertion is energy. For well-exerted energy, neither too lax nor too strained, arises in him in association with insight.

Then passage XXII:35 provides an explanation of the benefits of right energy, calling it 'right endeavor' and depicting it like a gatekeeper to good and bad karmic fruits:

\footnotetext{
${ }^{171}$ Ibid., 145.

172 Ibid., 497.

${ }^{173}$ Ibid., 519-20.

${ }^{174}$ Ibid., 544.

${ }^{175}$ Ibid., 659.
} 
XXII:35 ...it is endeavor because of bringing about improvement and giving precedence (padhana-bhava-karana) in the sense of producing well-being and bliss, thus it is right endeavor. It is a name for energy. It accomplishes the functions of abandoning arisen unprofitable things, preventing the arising of those not yet risen, arousing unarisen profitable things, and maintaining those already arisen; thus it is fourfold. ${ }^{176}$

Having found surprisingly little corroborating evidence in exploration of the term viriya, the next term of inquiry also holds more potential for real discovery. Part of this potential is in its linguistic relationship with the Sanskrit word 'präṇa'. As one might surmise, the term is pāna (breathing thing, living thing). First we find 'breathing thing' mentioned briefly in I:40:

...this is said in the Patisambhida...In the case of killing living things, (a) abandoning is virtue, (b) abstention is virtue, (c) volition is virtue, (d) restraint is virtue, (e) non-transgression is virtue" (49) "Such virtues lead to non-remorse in the mind, to gladdening, to happiness, to tranquility, to joy, to repetition, to development, to cultivation, to embellishment, to the requisite [for concentration], to the equipment [of concentration], to fulfillment, to complete dispassion, to fading away, to cessation, to peace, to direct knowledge, to enlightenment, to nibbana' (Ps.i,46-47). ${ }^{177}$

However, passage IX:54 renders a much more useful description of pāṇa:

Breathing things (pana): so called because of their state of breathing (pananata); the meaning is, because their existence depends on in-breaths and out-breaths. Creatures (bhuta): so called because of being (bhutatta = becomeness); the meaning is, because of their being fully become (sambhutatta), because of their being generated (abhinibbattata). Persons (puggala): 'pum' is what hell is called; they fall (galanti) into that, is the meaning. Peresonality (attabhava) is what the physical body is called; or it is just the pentad of aggregates, since it is actually only a concept derived from that pentad of aggregates. [What is referred to is] included (pariyapanna) in that personality, thus it 'has a personality' (attabhavapariyapanna). 'Included in' is delimited by; 'gone into' is the meaning'. ${ }^{178}$

\footnotetext{
${ }^{176}$ Ibid., 703.

${ }^{177}$ Ibid., 50 .

${ }^{178}$ Ibid., 303.
} 
Though it is a stretch to surmise that pāna are so called because they survive on an implied form of prana (as assāsa-passāsa) based solely on this passage, the concept is not so farfetched when stitched into the comprehensive image of 'breath' in the

\section{Visuddhimagga.}

Lastly, we take a glance at the term so many students and scholars have studied before, änäpāna (breathing), but the intention here is not to approach the term as a meditative tool, but as a possible indicator of cosmology. The first passage containing reference to änäpanna is III: 105 , and is simply a list of meditative topics:

The ten kinds of recollection are these: recollection of the Buddha (the Enlightened One), recollection of the Dhamma (the Law), recollection of the Sangha (community), recollection of virtue, recollection of generosity, recollection of deities, recollection (or mindfulness) of death, mindfulness occupied with the body, mindfulness of breathing, and recollection of peace. [111]. ${ }^{179}$

The second passage uses the word 'wind' to describe assäsa-passāsa, a word that we have already found to connote metaphysics more often than meditation:

VI:65 For one whose meditation subject is the four elements discerns the four primary elements in himself, one whose meditation subject is breathing discerns the wind in his own nostrils, and one whose meditation subject is a kasina makes a kasina and develops it at his ease, so that other meditation subjects are easily got. ${ }^{180}$

However the remaining passages all refer to ānāpāna as the traditionally accepted kasina:

VII:1 The mindfulness arisen inspired by breathing (ānāpāna) is mindfulness of breathing. This is a term for mindfulness that has as its object the sign of inbreaths and out-breaths. ${ }^{181}$

\footnotetext{
${ }^{179}$ Ibid., 110.

${ }^{180}$ Ibid., 183.

${ }^{181}$ Ibid., 192.
} 
VIII:43 Herein, the three, that is to say, the sections on postures, on the four kinds of full awareness (see MA.i,253f.), and on attention directed to elements, as they are stated [in that sutta], deal with insight. Then the nine sections on the charnelground contemplations, as stated there, deal with that particular phase of insight knowledge called contemplation of danger...So there are only the two, that is, the sections on breathing and on directing attention to repulsiveness, that, as stated there, deal with concentration. Of these two, the section on breathing is a separate meditation subject, namely, mindfulness of breathing. ${ }^{82}$

VIII:145 It has been recommended by the Blessed One thus: 'And, bhikkhus, this concentration through mindfulness of breathing, when developed and practiced much, is both peaceful and sublime, it is an unadulterated blissful abiding, and it banishes at once and stills evil unprofitable thoughts as soon as they arise' (S.v,321;Vin.iii,70). ${ }^{183}$

That is, all except for VIII: 145 which depicts mindfulness of breathing as banishing and stilling "evil unprofitable thoughts' just as energy is said to do in XXII:35. We can deduce that from these apparently separate mechanisms which perform the same function, that perhaps they are not so separate after all.

So concludes the exposition of the concept of assāsa-passāsa ('breathing out and in,' 'sign of life,' 'process of breathing,' and 'breath') in Bikkhu Nanamoli's translation of Buddhaghosa's Visuddhimagga. In a survey spanning the passages containing the terms: assāsa- passāsa, kāya- sankhāra, kāya- viññatti, vitthambhana, vāta, vāyo, ānāpāna, pāṇa, viriya, viññana $a$, and citta samutțhana, the groundwork had been laid to draw a comprehensive image and analysis of 'breath' in the Visuddhimagga. Of the ninety-five passages presented here, thirty-nine give potential indication of a metaphysical breath, and from this, the hypothesis of a present and unstated cosmology can be drawn.

\footnotetext{
${ }^{182}$ Ibid., 336.

${ }^{183}$ Ibid., 260.
} 


\section{Critical Theory}

\section{Background}

"An academic is concerned with the pursuit of truth; a Buddhist is concerned with living in accordance with, living in pursuit of dhamma."184

Let us now come to a discussion of scholastic opinions regarding the matter of Theravada cosmology and systems of metaphysics. It has long been recognized that Theravada Buddhism wants nothing to do with cosmological or metaphysical discussion. King writes, “...theorizing about ontological metaphysical ultimates has absolutely no place in the Buddhist Dharma." 185 Arthur Waley, in his introduction to Edward Conze's "Buddhism" says the same about philosophical exercises within Buddhism-they simply don't belong. ${ }^{186}$ For the most part, this observation has prevented serious scholastic inquiry into the subject, that is, it had until recently.

Strict Theravadins too, have been apt to avoid such questions because of the example the Buddha made of his disciple Malunkyaputta. According to Sutta sixty-three of the Majjhima Nikaya, Malunkyaputta approached his Teacher with questions of ontologyexistence, the nature of the universe, etc. The Buddha's response was to make the metaphor of a man pierced by a poisoned arrow. He asked Malunkyaputta what sense it would make for the man to question his surgeon about hereditary and educational

${ }^{184}$ Carter, John Ross, Dhamma as a Religious Concept: Its History in the Western Academic Tradition and its Centrality within the Sinhalese Theravāda Tradition. Journal of the American Academy of Religion 44 (4) $(12 / 01)(1976): 662$.

${ }^{185}$ Winston L. King, The Existential Nature of Buddhist Ultimates. Philosophy East and West 33 (3) (Jul.) (1983): 263.

${ }^{186}$ Conze, Edward, Buddhism : Its Essence and Development. Fir Harper Colophon ed. (New York: Harper \& Row, 1975), 15. 
qualifications, the model of arrow, or the distance from which it came before letting the surgeon remove the arrow and apply the poison's antidote forthright. Surely that man would be dead before the surgeon could tend to all of his questions. The Buddha explained that there was neither time nor necessity for spiritual aspirants to attempt an understanding of all these things, and that the real and only concern of humankind is the removal of suffering and realization of nibbana...neither of which require cosmological or metaphysical philosophies to be achieved. ${ }^{187}$

And while the various forms of Mahayana Buddhism promptly disposed of the Buddha's instructions warning against metaphysical, cosmological, and philosophical questions, the Theravadins have steadfastly adhered to his words and Malunkyaputta's example - at least they have according to official reputation and record. In reality, the 'Theravadin' Buddhist population of Sri Lanka has been mixing Brahmanism, indigenous, and other folk practices with Buddhism since Buddhism was brought to the island. Their syncretic form of Buddhism has been a constant factor from ancient through modern times and was certainly present during the writing of the Tipitaka, the Visuddhimagga, and Nanamoli's translation of Buddhaghosa's work. However, within the Mahavihara and its associated monastic communities, only the purest and oldest Buddhist doctrines are said to be preserved, practiced, and taught. The purpose of this thesis is to question, in part, the nature and integrity of these doctrinal messages by determining whether there is metaphysical use of the term assāsa-passāsa in the Visuddhimagga and whether the concept is similar to the Indian concept of prāṇa.

${ }^{187}$ Rahula, What the Buddha Taught, 12-15. 


\section{Scholars on Theravada Cosmology, Metaphysics and Breath}

The following scholars are ordered by the chronological publication of their works (though Nyanaponika Thera and Edward Conze overlap, as do Noa Ronkin, Ellison Banks Findly, and Georg Feuerstein) and represent the last century of discourse surrounding the concepts of cosmology, metaphysics, and ontology in Theravada Buddhism

Nyanaponika Thera. Nyanaponika Thera gives a good introduction to the Theravada perspective of breath and to the orthodox stance on metaphysics, appropriately by not addressing the subject. He does, however, talk about the purification of the mind being tantamount to enlightenment in his book, "The Heart of Buddhist Meditation." The third chapter covers the contemplations and exercises in meditation. The first topic is contemplation of the body and begins with mindfulness of the breath, ānāpāna-sati. Its purpose is to soothe mental and physical unrest and is used alternately as a subject for tranquility meditation, to induce the Absorptions, or to develop intimate observation of anicca in vipassana (wisdom meditation). Furthermore, he writes that breath is traditionally said to represent the state of the body and is of the wind element. ${ }^{188}$

In Chapter Six, Nyanaponika speaks specifically about ānāpāna-sati. Here, clear direction is given to the meditator cautioning against control of the breath, and not only is it insisted, Thera emphasizes non-regulation of the breath over several pages, driving its importance. ${ }^{189}$ It is possible that he is indicating an implicit 'intelligence' of breath over

\footnotetext{
${ }^{188}$ Ibid., 62-63.

${ }^{189}$ Ibid., 108.
} 
mind and body. Generally speaking though, Nyanaponika leaves us with a vision of the Mahavihara's pure interpretation of breath as a meditative tool and nothing more.

Edward Conze. One of the original and pre-eminent Buddhist scholars, Edward Conze, designates a small section of his book, "Buddhism" to a discussion of Buddhist cosmology. Among the informed, it is no secret that even the most orthodox Theravadin texts contain mention of the realms of existence, creatures that live therein, and universal cycles of creation and destruction. Conze writes that these explanatory cosmological structures were simply borrowed from the Hindu traditions contemporary to the Buddha, but it is unclear whether the Buddha spoke on any such matters. ${ }^{190}$

In much the same way, when Conze explains the concept of the Buddha's "glorified body", it is impossible to know if the Buddha ever spoke or taught of it. For the concept is not only metaphysical, and therefore officially taboo to the Theravadins, it is older than Buddhism, dating back to an astrological book belonging perhaps to the Indus Valley civilization. Nonetheless, every school of Buddhism, Theravada included, believes in the glorified body, an 18 foot tall, superhuman body of radiance, "the body which expresses the Buddha's own true nature."191 It is said to be identifiable by at least 32 signs and to be without temporal-spatial limitations. Conze quotes Vibasha on page 38 saying, "Around the body of the Buddha there is always a light, a fathom wide, on all sides, which shines

\footnotetext{
${ }^{190}$ Conze, Edward, Buddhism : Its essence and development, Fir Harper Colophon ed. (New York: Harper \& Row, 1975), 49.

${ }^{191}$ Ibid., 36-37
} 
constantly day and night, as brilliantly as a thousand suns, and resembling a mountain of jewels in movement." 192

What Conze has recorded here is most similar to the description of a saint's aura, a very old metaphysical concept in India and elsewhere, and essentially the result of transmuting an ordinary body and its energy fields into a superconductive, supernatural version of its former being. In traditional Indian terminology, the Sanskrit term for this effusive 'light substance' is prāṇa.

In Conze's sequel to Buddhism, Buddhist Texts through the Ages, he references a number of Nikayas on the topic of purity and directs attention to the ways through which purity is said to be achieved. One of the texts he presents is an English translation of the Majjhima-nikaya I 55-63, and in it, the "one way...for the purification of beings" is prescribed. ${ }^{193}$ And the very first step of this way is mindfulness of the breath. Contrary to the mainstream understanding of änāpāna-sati like we see with Nyanaponika in The Heart of Buddhist Meditation, Majjhima-nikaya I 55-63 does not warn against intentional alteration of the breath. By absence of specification, the text implies that either way is permissible as long as the breath continues to be the thing observed. ${ }^{194}$

The role of breath changes in text forty-nine, the Digha-Nikāya II 337-38, where it is extolled as a thing which gives "life" (using the analogy of application of breath to yield

\footnotetext{
${ }^{192}$ Ibid., 38.

${ }^{193}$ Conze, Edward, Buddhist Texts Through the Ages: Translated from Pali, Sanskrit, Chinese, Tibetan, Japanese and Apabhramsa, Harper torchbooks. Cloister Library, (New York: Harper \& Row, 1964), 56. 194 Ibid.
} 
sound) to a conch shell and is compared to the vital forces which activate the body. ${ }^{195}$ It seems the purpose of the term in this context is to express the inertia and emptiness of the body and entire material world while simultaneously assigning a definite animating property to breath. In Maurice Walshe's translation of this passage of the Dïgha-Nikäya, he writes that the animating forces in humans are "life, heat, and consciousness." 196 In the translation Conze recruits for Buddhist Texts through the Ages, the non-existence of self is reemphasized in text fifty-five, the Samyutta-Nikāya II, 114-15, where disciples are warned not to interpret feelings and impulses as one's self or part thereof ${ }^{197}$ and then again in text seventy-nine, the Sutta-Nipata 920 , monks are instructed that when at the center of experiencing "himself", "nowhere should he swell,"198 meaning that movement is not reality. This does not preclude an 'animating force' from being reality, but it is also not 'self' or 'identity.'

Then, under Conze's discussion on the Buddha, the concept of breath takes a decidedly different role. In texts one-hundred and sixteen and one-hundred and seventeen, the Majjhima-Nikaya I 69-72, it is a lion's roar which is a sign and right of a Tathagata. ${ }^{199}$ It seems likely that this particular description is a Sinhalese embellishment given that Sinhala means 'lion people' and the lion is the penultimate emblem of the secular Sinhalese identity. Origins aside, the Tathagata's sign and right is the roar, not

195 Ibid., 72.

${ }^{196}$ Walshe, Maurice O'C, The Long Discourses of the Buddha: A Translation of the Digha Nikäya, The Teachings of the Buddha, (Boston: Wisdom Publications, 1995), 360.

${ }^{197}$ Conze, Buddhist Texts through the Ages, 75.

198 Ibid., 90.

${ }^{199}$ Ibid., 110-112. 
the lion itself, lending still more evidence to the theory of a Theravadin ontological belief in the great power of breath.

In another of Edward Conze's books, Buddhist Meditation, he actually writes that as a starting point in the meditative continuum, Buddhism (Theravada included) uses prānayama, or as he puts it, regulation of life-force/breath. ${ }^{200} \mathrm{He}$ continues to say that though Yogic breathing is essential to creating physiological and mental calm, Buddhism urges restraint in using prānayama to control physiological processes, always reminding practitioners that the body is inherently unclean. ${ }^{201}$ His decision to use the word prānnayama is intriguing because in no other context or reference does anyone equate ãnāpāna-sati with prāṇayama in Theravada Buddhism. Conze does not go any farther with the idea. But we can assume that he has either mistakenly used the term pränayama or he is indicating that the idea of prāna exists in all of Buddhism. What's more is that he exposes a largely ignored orthodox cosmology and ontology present in the earliest Pali texts.

Wapola Rahula. Rahula provides two important tenets of Theravada in What the Buddha Taught. First, he describes how viññāna (consciousness) is, in no way to be equated to spirit, soul, self, or ego. In fact, these three ideas are non-existent in the school. ${ }^{202}$ Second, Rahula goes on to explain the actuality of movement:

There is no unmoving mover behind the movement. It is only movement. It is not correct to say that life is moving, but life is movement itself. Life and movement

\footnotetext{
${ }^{200}$ Conze, Edward, and Buddhaghosa, Buddhist Meditation, (London: Allen and Unwin, 1956), 29.

201 Ibid., 31.

${ }^{202}$ Rahula, What the Buddha Taught, 23.
} 
are not two different things. In other words, there is no thinker behind the thought. Thought itself is the thinker. ${ }^{203}$

Then, if life is movement and vice versa, wouldn't there be a single defining term for this concept? Paticcasamuppãda explains what is moving but fails to identify what this 'movement', this 'life' is. It is likely among the borrowed cosmological elements taken from Indian philosophy, that traces of the concept of prāna would have been taken piece by piece to fill unsightly voids in the 'mechanics' of paticcasamuppāda.

Winston L. King. Reiterating the Theravada scholastic approach, Winston King begins his article, "The Existential Nature of Buddhist Ultimates" by extracting the Buddha's original stance on metaphysics as the Pali Canon portrays it. That is, he reminds his audience that metaphysical inquiry and Buddhism were never supposed to co-exist as a system. ${ }^{204}$ However, this did not mean that metaphysics, cosmology, and ontology were not a part of Theravada Buddhism; instead King says they were the implicit side of the dhamma's explicit "existentialist/experiential prescription." In other words, the Brahmanical philosophical base was assumed and absorbed but dismissed as unimportant and never discussed. ${ }^{205}$

King argues two points in his article. First, he refutes the notion that Buddhism has had to "forsake" its simple prescriptive origins for the more enticing conjuncts of metaphysics and ontology. And secondly, he explains that much of the language used in Buddhism is purposefully vague so as not to give false ideas about the reality which is only capable of being directly experienced and not described, an idea of strong similarity

\footnotetext{
${ }^{203}$ Feuerstein, Prāna, 7362.

${ }^{204}$ King, The Existential Nature of Buddhist Ultimates, 263.

205 Ibid., 264.
} 
to Rudolf Otto's numinous. ${ }^{206}$ His conclusion is that there is not direct metaphysical language in the texts.

Noa Ronkin. Noa Ronkin is one of the only scholars to devote her academic efforts to the study of ontology and metaphysics in early Theravada Buddhism. In her book, "Early Buddhist Metaphysics," Ronkin demonstrates the extent to which Theravada expresses its cosmology through the terms anatta (non-self) and anicca (impermanence) as she writes,

...the Buddhist conception of change and continuity...[consists] solely in the causal connectedness between impermanent processes, rather than in an immutable substance underlying change in its secondary qualities. It exemplifies that the notions of continuity and identity are meaningful, although they do not imply the existence of any metaphysical principle that makes encountered phenomena continuous and identifiable. ${ }^{207}$

The above explanation of the mechanics of existence was the original message of the Buddha, according to the Pali Canon, that she argues became muddled with Brahmanical metaphysical verbiage during Theravada's early history. She refers to it as Buddhism's original process epistemology and goes on to argue that paticcasamuppäda can be called "process metaphysics," a term indicating that kammic rather than physical or substantive contact is causation enough to create phenomena. ${ }^{208}$ But like every other Theravada

\footnotetext{
${ }^{206}$ Ibid., 264-265.

${ }^{207}$ Ronkin, Noa, and NetLibrary Inc, Early Buddhist Metaphysics [electronic resource]: The Making of a Philosophical Tradition. (New York: RoutledgeCurzon, 2005), 201.

208 Ibid., 202-205.
} 
scholar, she confines her interpretation to the ambits of Whitehead's non-material Process Philosophy.

To summarize paticcasamuppāda, it is the explanation of how everything came, comes, and will come to be. Understanding dependent co-arising is said to be the achievement of enlightenment, itself. The cycle begins with ignorance, then karmaformations arise, which yield conditioned consciousness, which bears physical and mental formations, which give way to the sense organs and the mind, which enable sensation, which induce 'thirst' or cravings and aversions, which in turn leads to clinging, which conditions the process of becoming, which leads to birth, which leads inevitably to suffering and death. Then the cycle repeats incessantly, each link relying on the others to exist. $^{209}$

Ronkin also points out the interdependent 'consciousness' and 'name-and-form' are fundamentally and jointly responsible for producing one's life. To further illustrate the complexities of paticcasamuppāda, she explains that $\bar{a} y u$ (life-force) has the same relationship with the faculties of the body, both enabling and being enabled by $u s m \bar{a}$ (heat). Lastly, and significantly, she describes how the word paccaya, the circumstance which actively enables the arising of a phenomenon, is used in the Abhidhamma to give name to the kammic impetus responsible for carrying paticcasamuppãda. ${ }^{210}$

It is worth mentioning that Bhikkhu Ñanamoli does not translate $\bar{a} y u$ to mean 'lifeforce' in the Visuddhimagga. He simply calls it 'life', and in his glossary, gives it no

\footnotetext{
${ }^{209}$ Rahula, What the Buddha Taught, 53-54.

${ }^{210}$ Ibid., 208-213.
} 
specific point of reference in the text, thus indicating its unimportance. ${ }^{211} \mathrm{He}$ also gives no reference for paccaya, but defines it as 'condition' or 'requisite' for that which is conditionally arisen and for "the four for the Bhikkhu." 12

Incidentally, both terms Ronkin identifies as holding metaphysical significance are given only cursory attention in the Visuddhimagga. This either means that Buddhaghosa gave the terms reasonable attention but Bhikkhu Nanamoli decided not to give them importance in the translation, or that Buddhaghosa saw little importance in the terms as they had been represented by the Pali and Sinhalese texts. Considering Buddhaghosa and Ñanamoli's reputations for perspicacious collating and translation, the most likely explanation is that neither the Tipitaka nor the Visuddhimagga gives central importance to $\bar{a} y u$ or paccaya.

Though responsible for contributing significant developments in the field of Theravada metaphysics and being among the first and most vocal to do so, Ronkin's process epistemology does not address the possible existence of a vital animating force, much less the participation of assäsa-passäsa in metaphysical discourse.

Ellison Banks Findly. To specifically address the question of whether assāsapassāsa is similar to prāna and Indian metaphysics, Ellison Findly's contribution of the article, "Breath and Breathing" in the Encyclopedia of Religion serves as a bridge between Indian religions and Theravada Buddhism. Of the Hindu prāna he writes that it ...can refer to breath, respiration, life, vitality, wind, energy, and strength. In general, it is used in the plural to indicate vital breaths in the body, but is also related to speculation about the individual soul. Early Indian literature proposed a variety of notions about the relation between human breath (prāna), its natural

\footnotetext{
${ }^{211}$ Nanamoli, Visuddhimagga, 886.

212 Ibid., 890.
} 
correlate the atmospheric wind, and the cosmic order. The most important of these equated the atmospheric wind with the breath of Purusha, the cosmic man (Rigveda 10.90.13) who was, like the Egyptian god Amun, a deity manifest in the wind, and, as breath, the mysterious source of life in men and animals...The Brahmanas and Upanishads equate breath, as "vital breath," with the atman or soul (cf. German Atem, "breath") and with brahman, the cosmic essence. The vital air in the upper part of the body is here thought to be immortal and to be the inspirer of thoughts. ${ }^{213}$

Findly also outlines the five 'breaths' of the body (prānas) and five lesser 'winds' (vayus) that Indian medicine recognizes in the human body. Prānapānan is the term used to indicate the process of breathing. ${ }^{214}$ Interestingly, each of these aspects of prāna is spoken of separately and by varying names in the Visuddhimagga, and more importantly, none is left out.

When Findly discusses breath in the context of Theravada Buddhism, he only mentions ānäpāna-sati, and naturally so, in accordance with scholastic tradition. He describes it as 'respiratory discipline' but then contradicts himself by explaining that the meditator is not supposed to discipline the breath-the only action, the only explanation, and the only goal is the development of full awareness. ${ }^{215}$ So Findly takes the orthodox Theravada position on breath only to unwittingly provide a strong comparative parallel to prāna in the Hindu context.

Georg Feuerstein. Though not a specialist in Buddhism, Feuerstein is par excellence in the field of Indian Yogic studies. His Encyclopedia of Religion entry, "Präna," contributes additional depth to the definition Findly gives. First, and most

${ }^{213}$ Findly, Ellison Banks, Encyclopedia of religion; breath and breathing, ed. Lindsay Jones. 2nd ed. Vol. 2. (Detroit: Macmillan Reference USA, 2005), 1043.

${ }^{214}$ Ibid.

${ }^{215}$ Ibid., 1045. 
symbiotically to Buddhism, Feuerstein lists one of the six primary definitions of prāna to be "the life organs (i.e., the five cognitive senses, the five conative senses, and the senserelated mind, or manas). ${ }^{, 216}$ His definition fits more than conveniently into the Theravada Buddhist version of an 'ontological' philosophy, paticcasamuppāda (dependent coarising).

'Dependent co-arising' is a logically-connected sequence, into which it appears prāna can be inserted. But Feuerstein, like Findly, notes Theravada's aversion to the concept of a vital animating force, writing "Most metaphysical schools of India—one of the exceptions being Hinayana [Theravada] Buddhism—subscribe to this notion, although the details of interpretations differ." ${ }^{217}$ Curiously, Feuerstein observes that Theravada Buddhism is a "metaphysical school". Unfortunately, he gives no clue as to where he either found the description or came to said conclusion. And like Findly, Feuerstein gives a description of prāna which appears in the Visuddhimagga, only this time, under discussions of viñ̃āạna.

\section{Patterns, Analysis, and Conclusions}

\section{Evidence of a Metaphysical Assāsa-passāsa in the Visuddhimagga}

We have come to see how the face and texts of Theravada Buddhism and the Buddha himself firmly maintain that Buddhism holds no place for metaphysics, yet some scholars are just as ready to admit that the ontological philosophy of Theravada Buddhism is the proverbial elephant in the living room. A handful of scholars like Noa Ronkin has even

\footnotetext{
${ }^{216}$ Feuerstein, Prāna, 7362.

${ }^{217}$ Ibid.
} 
begun to go beyond cursory concession, and is now directly addressing the presence of metaphysics in the writings of orthodox Theravada Buddhism. ${ }^{218}$

Like the last type of scholar, this paper confronts a previously dismissed aspect of Pali Buddhist writings, namely, a metaphysical conception of breath in the Visuddhimagga, and by association, in the Pali Tipitaka and entire Theravadin School.

In the search through Bhikkhu Nanamoli's translation of Buddhaghosa's Visuddhimagga for indication of a metaphysical assāsa-passāsa, three distinct patterns emerged. The first is that the terms for 'wind' and 'air' are referenced predominantly in cosmological passages but can also be used to refer to breath, indicating an ontological nature thereof. Secondly, consciousness is neither equated with breath nor is it an animating force, but independently gives rise to assāsa-passāsa. Thirdly, assāsa-passāsa is the only component of the human body which originates from consciousness alone, and nothing external to the body can be consciousness-originated, therefore atmospheric air is not assāsa-passāsa. Assembled, these findings support the hypothesis that assāsapassāsa not only resembles the Indian metaphysical concept of prāna, it is an animating vital force and intermediary between links in the chain of dependent co-arising.

Air, Wind, and Cosmology. Buddhaghosa is not shy about recording cosmological systems of the Tipitaka and early commentaries in the Visuddhimagga. As seen in the earlier expository chapter, he references some of the realms of existence, from the Avici hell to the heaven of the Paranimmitavasavatti deities as they are described in Vibhanga 86 (Abhidhamma). ${ }^{219}$ Buddhaghosa proceeds to discuss the forces of vāta and $v \bar{a} y o$ as

\footnotetext{
${ }^{218}$ Ronkin, Early Buddhist Metaphysics.

${ }^{219}$ Buddhaghosa and Nānamoli, The Path of Purification [Visuddhimagga], 493.
} 
they behave in the creation and destruction of certain eons in XIII:30, XIII:42, and XIII:59. ${ }^{220}$ The importance of these passages lies in their assumption of the cosmological properties and predictions of which they speak - the implicit Theravada cosmology borrowed from Brahmanism and the powerful motile property of wind and air.

In reference to the air element, Buddhaghosa lists its quality as distension, its function as causing motion, and its manifestation as "conveying" in XI:93. ${ }^{221}$ Its primary quality vitthambhana, 'distension' is described in the note to X1:24 as causing the appearance of motion, supporting other substances, or giving a stiffening effect. ${ }^{222}$ The description gives a reasonable account of 'air' as an animating force in the human body while XI: 107 differentiates between 'air' and 'wind' external to the body and the kind within the body. The elements outside of the body (air included) are said to be opposite to those within. And those within are responsible for supporting the physical bases of consciousness, intimation, and material faculties. ${ }^{223}$ If the internal and external elements are indeed opposite, it would mean that consciousness, intimation, and all the perceptual faculties require a body (presumably human) to exist and vice versa and as stated, that breath is intrinsically different from atmospheric air.

Passage XI:37 makes this distinction all the more clear with its definition of vāyo, a description worth revisiting here:

Air ( $v \bar{a} y o)$ [is definable] as blowing (vayana). The airy (vāyo-gata) is what is gone (gata), in the way already described, among the kinds of air. What is that? It

\footnotetext{
${ }^{220}$ Ibid., 410-416.

${ }^{221}$ Ibid., 360.

${ }^{222}$ Ibid., 796-797.

${ }^{223}$ Ibid., 363.
} 
is what has the characteristic of distension. Up-going winds: winds (forces) mounting upwards that cause the occurrence of vomiting, belching, and so on. Down-going winds: winds (forces) descending downward that expel excrement and urine. Winds in the belly: winds (forces) outside the bowels. Winds in the bowels: winds (forces) inside the bowels. Winds that course through all the limbs: winds (forces) that produce flexing, extending, etc., and are distributed over the limbs and the whole body by means of the network of veins (nerves). In-breath: wind in the nostrils entering in. Out-breath: wind in the nostrils issuing out. And here the first five are of fourfold origination. In-breath and out-breath are consciousness-originated. $[\mathbf{3 5 1}]^{224}$

Both Feuerstein and Findly explain the types of präna flowing throw the body in nearly identical terms as Buddhaghosa has. ${ }^{225226}$ Unquestionably, Buddhaghosa has recorded a description of the 'vital breaths' and the nadis, or channels (nerves or veins, as he records them) through which they flow, proving that the concept of präna was part of the Tipitaka.

Consciousness. Consciousness is neither equated with breath nor is it an animating force. These two points are emphasized and re-emphasized repeatedly in the Visuddhimagga. It can, however, be creative (of matter), but again, there is no mechanism for this creation given. The process is given as 'kamma-arisen', another causative property without mechanical explanation. Like many Indian constructs of prāṇa maintain, breath is not consciousness; instead, prāṇa (assāsa-passāsa) is an intermediary functioning between energy, consciousness, and physical matter.

Assāasa-passāsa, Sui Generis. Assāsa-passāsa is the only component of the human body which originates from consciousness alone, and nothing external to the body can be

\footnotetext{
${ }^{224}$ Ibid., 346.

225 Findly, Breath and Breathing, 1043.

226 Feuerstein, Prāna, 7362.
} 
consciousness-originated. It is understood in contemporary science that oxygen is necessary for life, and if a person should cease to breathe, that person would quickly perish. There are a number of such statements in the Visuddhimagga. For example, Buddhaghosa writes, "...the life of beings is bound up with breathing..."227 in VIII:27 and in IX:54, "Breathing things (pāna): so called because of their state of breathing (pananata); the meaning is, because their existence depends on in-breaths and outbreaths" 228 and so on. He also talks frequently of the tranquilizing effect änäpäna-sati and assāsa-passāsa have on the mental and physical bodies. ${ }^{229}$

The human dependency on breathing would seem fairly obvious and unlikely to represent a metaphysical understanding of breath were it not for the aforementioned divide between the 'wind' within and the 'wind' without. The text is not simply taking about oxygen. It is referring to a substance which is generated by consciousness and performing functions external air is incapable of performing.

$\mathrm{I}: 53,57$, and the note to I:14 describe the interaction which occurs between consciousness, the sense doors (eyes, ears, nose, tongue, tactile nerve endings, mind), and their objects. ${ }^{230}$ Likewise XIV:61 shows how consciousness generates internal air, which causes bodily intimation, which inspires bodily excitement, which displays intention. ${ }^{231}$ In both of these descriptions, the absence of an intermediary substance or mechanism (other than the vague causal links of paticcasamuppāda) makes the descriptions appear

\footnotetext{
${ }^{227}$ Buddhaghosa and Ñānamoli, The Path of Purification [Visuddhimagga], 231.

${ }^{228}$ Ibid., 303.

${ }^{229}$ Ibid., 183, 260, 267.

${ }^{230}$ Ibid., 23, 24, 751.

${ }^{231}$ Ibid., 448.
} 
incomplete. This is, however, without considering the implicit ontological structure of the universe that readers of the Visuddhimagga were expected to have. By inserting these metaphysical principles, including the animating and intermediating vital force of prāna, rendered in the Visuddhimagga as assāsa-passâsa and its related terms, mental and physical processes of paticcasamuppāda become mechanically transparent.

Conclusion. Assembled, these findings support the hypothesis that assāsa-passāsa is not only an animating vital force but also an intermediary between links in the chain of dependent co-arising, giving way to the 'how' of paticcasamuppäda. In response to the questions posed in the beginning of this paper, the concept assāsa-passāsa has been found to be similar to the Indian concept of prāna, a finding which indicates that Theravada Buddhism is not in fact unique among Indian religions for its lack of this concept, which contributes to a growing body of evidence proving that Theravada ontology exists, and which offers a more descriptive mechanical variation to the strict Process Philosophy/Epistemology paradigm that has been used to construct and deconstruct paticcasamuppāda thus far.

The findings of this paper suggest a number of trajectories for future projects, the first of which is the performance of a mirror investigation into Buddhaghosa's Visuddhimagga in its original Pali to test out the findings of this study. The same project could then be extended to include a survey of the entire Pali Tipitaka to reveal the face of assãsapassāsa as it appears in the Canon. This would be an enormous undertaking, but one with unique potential to understand Theravada metaphysics in a profound way.

Another neglected question is that of the specific contributions of the pre-Mahinda religions of Sri Lanka to the Tipitaka and Visuddhimagga. Which ideas came from where 
and whom? The potential of finding a far more infiltrated orthodox doctrine than commonly recognized is present in such a project.

Lastly, and most importantly, would be an inter-religious study on the concept of breath as a/the vital animating force. The addition of Theravada Buddhism to the list of religions with such a concept is a significant change which can now yield equally significant comparative studies. As human existence becomes ever more globalized, comparative studies continue to facilitate the harmonization of one with the "other", promoting peace by enabling common ground. 


\section{BIBLIOGRAPHY}

Adikaram, E. W. 1946. Early History of Buddhism in Ceylon: Or, State of Buddhism in Ceylon as Revealed by the Pâli Commentaries of the 5th Century A.D. Migoda, Ceylon, D: S. Puswella.

Buddhadatta, Ambalangoda Polvatte. 1957. Concise Pali-English Dictionary. Colombo: Colombo Apothecaries.

Bareau, André. 2005. Encyclopedia of Religion; Buddhism, Schools of: Early Doctrinal Schools of Buddhism, ed. Lindsay Jones. $2^{\text {nd }}$ ed., Vol. 2. Detroit: Macmillan Reference USA.

Bratcher, Robert G. 1983. Biblical Words Describing Man : Breath, Life, Spirit. Bible Translator (Ap, O Practical Papers) 34 (2) (04/01): $201-9$.

Buddhaghosa, and Bhikkhu Ñānamoli. 1991. The Path of Purification [Visuddhimagga]. $5^{\text {th }}$ ed. Kandy, Sri Lanka: Buddhist Publication Society.

Carter, John Ross. 2005. Encyclopedia of Religion; Buddhaghosa, ed. Lindsay Jones. $2^{\text {nd }}$ ed., Vol. 2. Detroit: Macmillan Reference USA.

Carter, John Ross. 1976. "Dhamma as a Religious Concept: Its History in the Western Academic Tradition and its Centrality within the Sinhalese Theravāda Tradition". Journal of the American Academy of Religion 44 (4) (12/01): 661-74.

Conze, Edward. 1975. Buddhism: Its Essence and Development. Fir Harper Colophon ed. New York: Harper \& Row.

Conze, Edward. 1964. Buddhist Texts through the Ages. Translated from Pali, Sanskrit, Chinese, Tibetan, Japanese and Apabhramsa. Harper Torchbooks. Cloister Library. New York: Harper \& Row.

Conze, Edward, and Buddhaghosa. 1956. Buddhist Meditation. London: Allen and Unwin.

Davids, T. W. Rhys, and William B. Stede. 1993. Pali-English Dictionary. $1^{\text {st }}$ ed. Delhi: Motilal Banarsidass Publishers.

De Silva, K. M. 1981. A History of Sri Lanka. London; Berkeley: C. Hurst; University of California Press.

Douglas-Klotz, Neil. 1997. "The Natural Breath : Towards Further Dialogue between Western Somatic and Eastern Spiritual Approaches to the Body Awareness of Breathing". Religious Studies and Theology 16 (2) (12/01): 64-79. 
Dowling, Elizabeth M., Sage Publications Inc., Sage eReference, and W. George Scarlett. 2006. Encyclopedia of Religious and Spiritual Development [electronic resource]. Thousand Oaks, California: SAGE Publications.

Feuerstein, Georg. 2005. Encyclopedia of Religion; Prāṇa, ed. Lindsay Jones. $2^{\text {nd }}$ ed., Vol. 11. Detroit: Macmillan Reference USA.

Findly, Ellison Banks. 2005. Encyclopedia of Religion; Breath and Breathing, ed. Lindsay Jones. $2^{\text {nd }}$ ed., Vol. 2. Detroit: Macmillan Reference USA.

Griffiths, Paul J. 1981. Concentration or Insight : The Problematic of Theravāda Buddhist Meditation-theory. Journal of the American Academy of Religion 49 (4) (12/01): 605-24.

Hamilton, Sue. 1995. "From the Buddha to Buddhaghosa : Changing Attitudes toward the Human Body in Theravāda Buddhism". In Religious Reflections on the Human Body., 46-63. Bloomington: Indiana University Press.

Katz, Nathan. 1989. Buddhist Images of Human Perfection: The Arahant of the Sutta Pitaka Compared with the Bodhisattva and the Mahāsiddha. $2^{\text {nd }}$ ed. Delhi: Motilal Banarsidass.

Keown, Damien, and Charles S. Prebish. 2007. Encyclopedia of Buddhism. New York: Routledge.

Lancaster, Lewis R. 2005. Encyclopedia of Religion; Buddhist Books and Texts: Canon and Canonization, ed. Lindsay Jones. $2^{\text {nd }}$ ed. ,Vol. 2. Detroit: Macmillan Reference USA.

"The Life of Osbert Moore, Also Known As Nanamoli Thera." Nanavira Thera Dhamma Page. 2009. http://nanavira.110mb.com/Thoughts_on_Nanamoli_sketch.htm (accessed January 2011).

Nyanaponika Thera. 1992. The Heart of Buddhist Meditation: Satipatthāna: A Handbook of Mental Training Based on the Buddha's Way of Mindfulness, with an Anthology of Relevant Texts Translated from the Pali and Sanskrit. $1^{\text {st }}$ BPS ed. Kandy, Sri Lanka: Buddhist Publication Society.

Nyanatiloka Bhikkhu, Corporate Body of the Buddha Educational Foundation, and Nyanaponika Thera. 1991. Buddhist Dictionary: Manual of Buddhist Terms and Doctrines. $3^{\text {rd }}$ ed. / it by Nyanaponika ed. Taipei, Taiwan: Corporate Body of the Buddha Educational Foundation.

Panabokke, Gunaratne B., and University of Kelaniya Postgraduate Institute of Pali \& Buddhist Studies. 1993. History of the Buddhist Sangha in India and Sri Lanka. 
Colombo, Sri Lanka: Postgraduate Institute of Pali and Buddhist Studies, University of Kelaniya.

Potter, Karl H. 1995. Encyclopedia of Indian Philosophies. $3^{\text {rd }}$ ed. Delhi: Motilal Banarsidass Publishers.

Prebish, Charles S. 2001. The A to Z of Buddhism. Lanham, Md.: Scarecrow Press.

Rāhula, Walpola. 1974. What the Buddha Taught. $2^{\text {nd }}$ ed. New York: Grove Press.

Reynolds, Frank E., and Regina T. Clifford. 2005. Encyclopedia of Religion; Theravāda, ed. Lindsay Jones. 2nd ed. Vol. 13. Detroit: Macmillan Reference USA.

Rice, Edward E., 1978. Eastern Definitions : A Short Encyclopedia of Religions of the Orient. 1 st ed. Garden City, N.Y.: Doubleday.

Robinson, Richard H., Willard L. Johnson, and Willard L. Johnson. 1977. The Buddhist Religion: A Historical Introduction. 2d ed. Encino, Calif.: Dickenson Pub. Co.

Ronkin, Noa, and NetLibrary, Inc. 2005. Early Buddhist Metaphysics [electronic resource]: The Making of a Philosophical Tradition. New York ; London: Routledge Curzon.

Tambiah, Stanley J. 1985. Purity and Auspiciousness at the Edge of the Hindu Context in Theravada Buddhist Societies. Journal of Developing Societies 1 (1): 94-.

Taimni, I.K. 1987. The Science of Yoga. Wheaton: The Theosophical Publishing House.

Walshe, Maurice O'C. 1995. The Long Discourses of the Buddha: A Translation of the Digha Nikäya. The Teachings of the Buddha. Boston: Wisdom Publications.

Winston L. King. 1983. The Existential Nature of Buddhist Ultimates. Philosophy East and West 33 (3) (Jul.): pp. 263-271. 